University of Louisville

ThinkIR: The University of Louisville's Institutional Repository

Electronic Theses and Dissertations

$5-2012$

\title{
Building bonds \& promoting healthy choices : farmers' \& vendors' relationships with African American consumers.
}

Natasacha Ryan Jones

University of Louisville

Follow this and additional works at: https://ir.library.louisville.edu/etd

\section{Recommended Citation}

Jones, Natasacha Ryan, "Building bonds \& promoting healthy choices : farmers' \& vendors' relationships with African American consumers." (2012). Electronic Theses and Dissertations. Paper 708.

https://doi.org/10.18297/etd/708

This Master's Thesis is brought to you for free and open access by ThinkIR: The University of Louisville's Institutional Repository. It has been accepted for inclusion in Electronic Theses and Dissertations by an authorized administrator of ThinkIR: The University of Louisville's Institutional Repository. This title appears here courtesy of the author, who has retained all other copyrights. For more information, please contact thinkir@louisville.edu. 
BUILDING BONDS \& PROMOTING HEALTHY CHOICES:

FARMERS' \& VENDORS' RELATIONSHIPS WITH AFRICAN

AMERICAN CONSUMERS

\author{
By \\ Natasacha Ryan Jones \\ B.A., University of Kentucky, 2010
A Thesis
Submitted to the Faculty of the
College of Arts and Sciences of the University of Louisville
In Partial Fulfillment of the Requirements
for the Degree of

\author{
Master of Arts \\ Department of Communication \\ University of Louisville \\ Louisville, Kentucky
}

May 2012 
Copyright 2012 by Natasacha Ryan Jones

All rights reserved 
BUILDING BONDS \& PROMOTING HEALTHY CHOICES:

FARMERS' \& VENDORS' RELATIONSHIPS WITH AFRICAN

AMERICAN CONSUMERS

By

Natasacha Ryan Jones

B.A., University of Kentucky, 2010

A Thesis Approved on

April 26, 2012

By the following Thesis Committee:

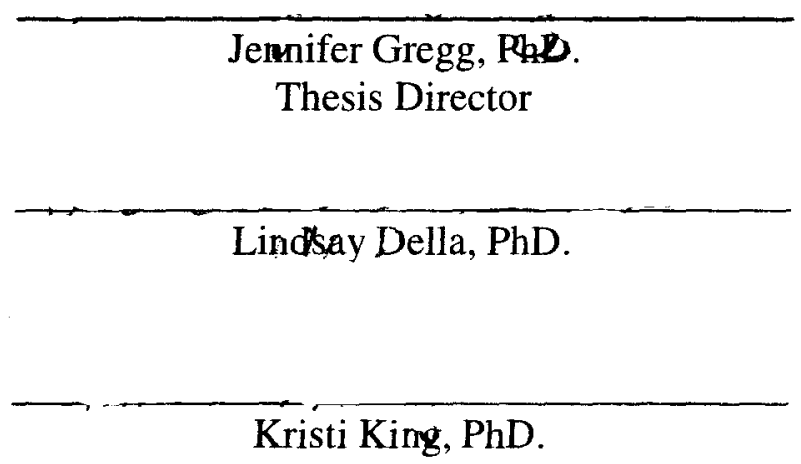




\section{DEDICATION}

This thesis is dedicated to two very special people in my life

\section{Roger Dean Cochran}

and

\section{Madison Alexis Cochran}

who have encouraged me and shown me that what seems

impossible just takes a little longer to accomplish so live a

little and believe. 


\section{ACKNOWLEDGEMENTS}

This journey would not have been possible without the guidance provided by my committee members, help from friends, and support from my family.

I would like to express my deepest gratitude to my thesis director, Dr. Jennifer Gregg for constantly inspiring and encouraging me throughout my studies these past two years. Although Dr. Gregg is a mother to two sons, she is also a mother to many of her students. This research is a tribute to her exceptional insight because she encourages students to shoot for the moon and to research topics of their interests. Without her wisdom, caring, patience and helping me overcome barriers, this thesis would not have been possible. I would like to thank Dr. Lindsay Della for helping me realize that sometimes you have to go back a few steps in order to discover concepts of greater concern and that no idea is ever too small for research. In addition, I would like to thank Dr. Della for guiding me and patiently helping me with my writing. I would also like to give a special thanks to Dr. Kristi King, who was willing to work with me and be a part of my committee.

I would like to thank Ryessia Jones and Lauren Hendricks, who were great friends. We could always count on one another under any circumstance and we succeeded because of our friendship. My research would not have been possible without their suggestions and help. The bonds that we built will never be forgotten.

I would also like to thank my beloved parents and step-father for supporting me and encouraging me with their best wishes. 


\section{ABSTRACT \\ BUILDING BONDS \& PROMOTING HEALTHY CHOICES: FARMERS' \& VENDORS' RELATIONSHIPS WITH THE AFRICAN AMERICAN CONSUMER}

Natasacha Ryan Jones

April 26, 2012

The purpose of this study is to obtain a better understanding of the interactions and the social environment of the local farmers' markets, Fresh Stops, and Healthy in a Hurry Corner Stores in West Louisville and East Downtown. This study will review some of the current literature on the local farmers' markets and Fresh Stops of Louisville while focusing on the perspectives of farmers and vendors who transport the fresh and fruits and vegetables into the communities. The experiences and perspectives of local farmers and vendors will provide insight on consumer trends and characteristics. Most important, this study will examine how the local farmers and vendors view the consumer response to the local farmers' markets, Fresh Stops and Healthy in a Hurry Corner Stores. The study also explores the role of communication as it is critical to awareness, healthy diet promotions, and as a mechanism for encouragement and increased fruits and vegetable consumption. To develop a clear understanding of the perspectives of farmers and vendors who interact with the African American consumers, in-depth interviews were conducted with participants connected with each organization. Data analyses were performed based on Owen's criteria to determine recurring and important themes. 


\section{TABLE OF CONTENTS}

\section{PAGE}

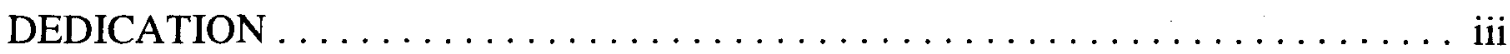

ACKNOWLEDGEMENTS $\ldots \ldots \ldots \ldots \ldots \ldots \ldots \ldots \ldots \ldots \ldots \ldots \ldots \ldots \ldots$ iv

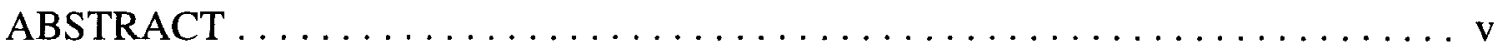

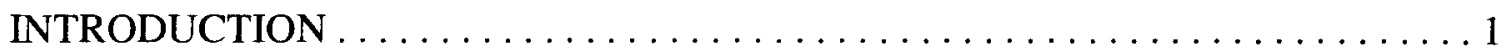

LITERATURE REVIEW $\ldots \ldots \ldots \ldots \ldots \ldots \ldots \ldots \ldots \ldots \ldots \ldots$

Nutritional Recommendations. . . . . . . . . . . . . . . . . . . 6

African American Diet and Health. $\ldots \ldots \ldots \ldots \ldots \ldots \ldots \ldots \ldots \ldots$

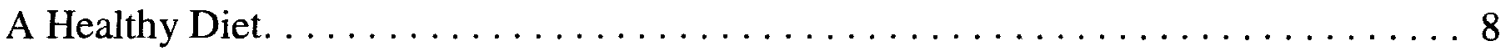

A Snapshot of Louisville, Kentucky $\ldots \ldots \ldots \ldots \ldots \ldots \ldots \ldots \ldots \ldots$

Community Farm Alliance $\ldots \ldots \ldots \ldots \ldots \ldots \ldots \ldots \ldots \ldots \ldots$

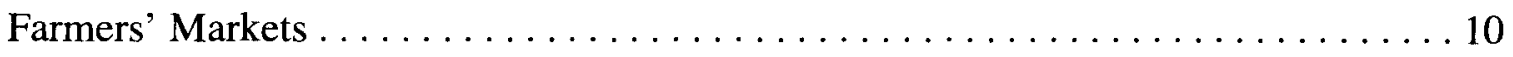

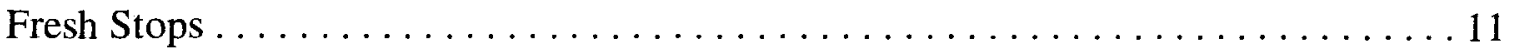

Healthy in a Hurry Corner Stores $\ldots \ldots \ldots \ldots \ldots \ldots \ldots \ldots \ldots \ldots \ldots \ldots \ldots \ldots \ldots \ldots \ldots$

African American View on Access to Healthy Foods. ................. 12

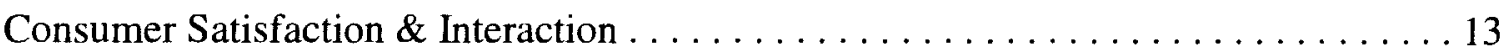

Perspectives of Vendors and Farmers $\ldots \ldots \ldots \ldots \ldots \ldots \ldots \ldots \ldots \ldots \ldots \ldots$

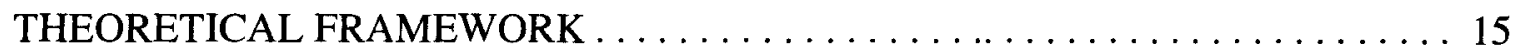

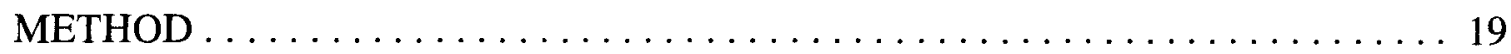

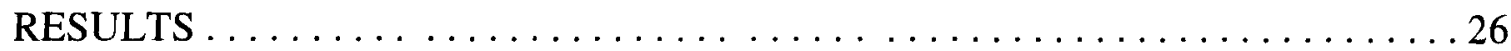




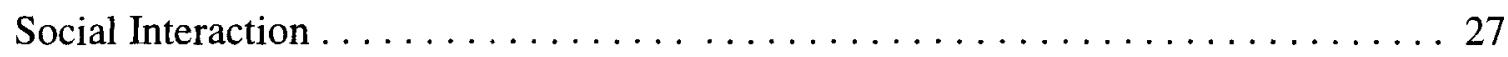

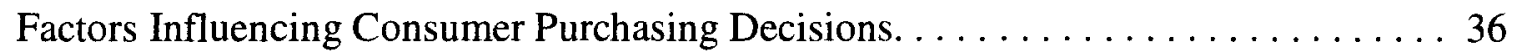

Additional Contributing Themes. . . . . . . . . . . . . . . . . 41

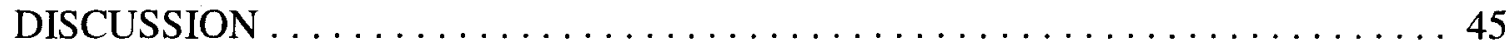

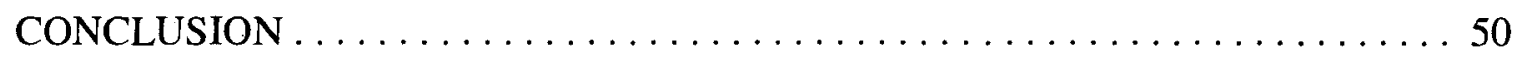

REFERENCES .............................. 54

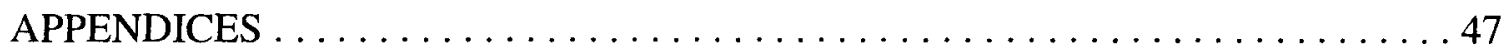

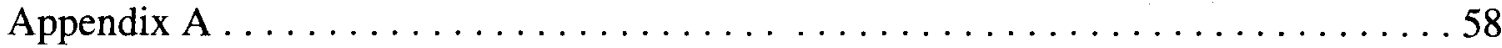

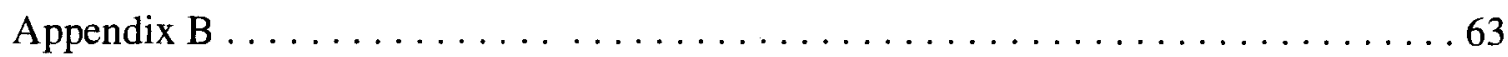

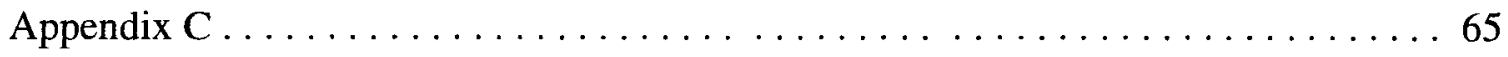

Appendix D . . . . . . . . . . . . . . . . . . . . 70

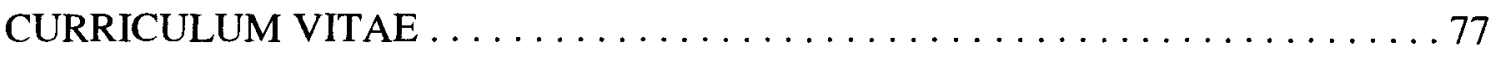




\section{INTRODUCTION}

The purpose of this study is to explore farmers' and vendors' perceptions of their influence on African American consumer behavior in West Louisville and East Downtown Louisville. The central focus is to obtain knowledge and a better understanding of suppliers' experiences with farmers' markets, Fresh Stops, and Healthy in a Hurry Corner Stores in this region of Louisville. This study will examine the feelings expressed by farmers and vendors in regards to their personal experiences, such as during their first morning in May when they begin to unload their fruits and vegetables for sale. Through these personal experiences, farmers and vendors will provide details about the many benefits and challenges of selling their produce in these markets, stops, and corner stores.

Local farmers' markets, Fresh Stops, and Healthy in a Hurry Corner Stores provide a great opportunity for farmers and vendors to interact with African American consumers. Farmers and vendors have the ability to inform the consumer about how the produce was grown. Further, the farmers' markets, Fresh Stops, and Healthy in a Hurry Corner Stores provide a great ambiance, allowing consumers to meet their local farmers, ask questions about the variety of available produce, and make educational choices about produce. 'These Farmers' Markets and Fresh Stops help build communities and bring people together" (Community Farm Alliance, 2007, p.i). 
The primary location for this study remains within Louisville, Kentucky; more specifically, West Louisville and East Downtown. West Louisville stretches North from the Algonquin Parkway and West from Roy Wilkins Drive. It includes the neighborhoods of Algonquin, Park Hill, Park DuValle, Chickasaw, Shawnee, Portland, California, Parkland and Russell (Community Farm Alliance, 2007, p.4). East Downtown is composed of the Phoenix Hill, Smoketown, and Shelby Park neighborhoods (Community Farm Alliance, 2007, p.5).

Food is very important throughout Jefferson County and the importance of fruits and vegetables is displayed through many of Louisville Metro government's initiatives to bring fresh produce to local communities. In particular, West Louisville and East Downtown were chosen as study locations because there are limited stores offering a variety of fresh fruits and vegetables. According to Louisville Mayor Greg Fischer's Healthy Hometown Movement, the local stores that residents have access to do not provide many healthy choices (State of Food, 2010, p.9). Moreover, the quality of fruits and vegetables available to consumers is often poor. Local initiatives such as the New Roots Fresh Stop Project, Louisville Farm to the Table Project, Healthy in a Hurry Corner Stores initiative, and several other projects, however, demonstrate a recent push to make fresh fruits and vegetables available to the people in these communities.

As this study primarily focuses on local suppliers who are bringing fresh fruits and vegetables into West Louisville and East Downtown, a greater understanding of the cultural values related to the African American diet can be obtained. This greater understanding is important because the African American population is disproportionately affected by dietary-related illnesses such as cardiovascular disease, 
obesity, and diabetes (African American Health Statistics, 2009). Obesity is rising faster in the African American population than in the white population (Strauss \& Pollack, 2001, p. 2847). Increasing rates of these dietary-related illnesses indicate even greater disparities in years to come. Local farmers and vendors may help provide additional insight into the factors that influence consumer choices about fruits and vegetables throughout the African American population in West Louisville and East Downtown.

Within the West Louisville and East Downtown communities, there is a desperate need to look for a brighter, healthier, and longer future. With insight from farmers' markets, Fresh Stops, and Healthy in a Hurry Corner Stores providers, Louisville health communicators can gain a better understanding of how local farmers might influence this process. Just as consumers learn about their farmers, the farm itself, and the produce, the farmers learn more about the African American consumers' diet and which fruits and vegetables are in high demand among the group. Understanding which fruits and vegetables African American consumers want enables farmers to grow what people want.

The topic of diet, particularly diet-related illnesses, is especially important within the field of health communication. One of the goals of health communicators is to improve the health of people. It is no secret that African American dietary habits pose great risks to their health status (Community Food Compact, 2011, farmtocity.org). The African American diet is one that is unique and essential to the identification of its culture. However, some of the literature indicates that there is a need to include more fruits and vegetables within the diet of this population and to adopt healthier food preparation methods (Centers for Disease Control and Prevention, 2010, cdcph.ca.gov). African Americans enjoy diets abundant in flavor and taste. Although some food 
preparation methods may not be the most appropriate health choice, these methods define certain aspects of the African American diet. For example, fruits and vegetables may be included in meals occasionally, but one must also consider the foods and spices such as ham hocks, bacon, seasoning salts, and gravies that are added to achieve the desired taste and flavor. These preparation methods conflict with heart-healthy recommendations (Cowling, 2008).

Through this study, the researcher will be better able to understand the role farmers and vendors play in shaping diet choices, as well as their role in educating and motivating African American consumers to purchase their produce and try different food preparation methods. For example, this study will explore whether some vendors offer recipes, suggest alternative ingredients, and recommend different cooking styles from those traditionally embraced by the African American population. The farmers and vendors will also be asked to provide their opinions about how well consumers accept these suggestions and recommendations. Finally, this study will explore how local initiatives (e.g. Fresh Stops) might be used to further encourage fruit and vegetable consumption and understand how suppliers influence consumer behavior within this audience.

Through active participation at local farmers' markets, Fresh Stops, and Healthy in a Hurry Corner Stores, it is possible that bonds may be created between farmers, vendors, and consumers. These smaller markets offer a more intimate setting, which allows a closer relationship between sellers and consumers. This study offers the opportunity to gain insight into if/how suppliers provide guidance and information about better food choices. Obviously, this study is timely and of major concern within the 
medical sciences. According to the Center for African American Health, African Americans are affected by serious diseases and chronic health conditions at far greater rates than other Americans. For example, African Americans have higher rates of obesity, are twice as likely to have diabetes, have the greatest chance of having heart disease, and experience the highest death rate from cancer (The Center for African American Health, 2012, caahealth.org). Therefore, this study will examine perceptions of the farmers and vendors who interact closely with the African American consumer, with the aim of providing a detailed and clear image of social interactions at the farmers' markets, Fresh Stops, and Healthy in a Hurry Corner Stores throughout Louisville, Kentucky. 


\section{LITERATURE REVIEW}

\section{Nutritional Recommendations}

The United States Department of Agriculture (2011) provides science-based nutritional guidelines for Americans ages two and older to promote healthy lifestyles and dietary habits. To date, the current recommended diet is six ounces of grains, two and one half cups of vegetables, two cups of fruit, three cups of milk for those over the age of eight, and five and one half ounces of meat and beans each day (USDA, 2011, ChooseMyPlate.gov). These recommendations have changed since the original food pyramid was developed in 1992 (USDA, 2011, News and Media). The new recommendations reflect current science and offer consumers more personalized approaches to eating healthy and participating in physical activity.

\section{African Americans Diet and Health}

According to Belle (2009), “African Americans have dietary preferences born from cultural influences and necessity. The preference for a particular type of cuisine called soul food has resulted in various health problems for African Americans." Soul food typically involves fried foods such as chicken and pork chops and "fatty meats prepared with rich gravies" (Belle, 2009). African Americans associate these foods with "social interactions" such as family gatherings and functions and "also with their history of slavery" (Belle, 2009). Belle (2009) also describes that any efforts to get African 
Americans to eat other types of healthier foods are met with resistance and are seen as trying to eradicate Black culture.

African Americans face their own culturally specific health issues and challenges (Better Nutrition Promoting, 2012). "The diet can be high in sodium and low in potassium, two major factors contributing to hypertension, and the diet may not include any fruits or vegetables" (Better Nutrition Promoting, 2012). African American adults, on average, consume only 4.3 servings of fruits and vegetables a day, compared to the statewide average of 5.2 servings (National Center for Health Statistics, 2002). Only 39 percent of African American adults eat 5 or more daily servings of fruits and vegetables, compared to 50 percent for all adults statewide (National Center for Health Statistics, 2002).

African Americans have one of the highest levels of obesity in the United States (Cowling, 2008). African American women have the highest rates of being overweight or obese compared to other groups in the United States. About four out of five African American women are overweight or obese. "Fifty-eight percent of African American men and 69 percent of African American women are either overweight or obese" (Cowling, 2008). The rate of Type 2 diabetes among African Americans is 1.6 times higher than that of the total United States population (Better Nutrition Promoting, 2012). Cardiovascular diseases (CVD) rank as the number one killer of African Americans, claiming the lives of over one-third of the more than 292,000 African Americans who die each year (Kung, C.H. et al. 2008). The American Heart Association (2009) reports the rate of high blood pressure in African Americans in the United States is among the highest in the world at about 44 percent. African Americans develop high blood pressure 
earlier in life and have much higher average blood pressures compared to whites, contributing to a higher rate of fatal stroke (American Heart Association, 2009).

\section{A Healthy Diet.}

According to Viswanath and Bond (2007), a healthy diet is considered a critical pathway to preventing or managing chronic health conditions such as hypertension, diabetes, cardiovascular disease, cancer, and obesity (p. S20). Current resources provided by the Centers for Disease Control and Prevention (2011) recognize the increasing existence of disparities of such diet-related illnesses among the African American population. Diet is an important determinant of chronic disparities. As stated in Dubowitz et al. (2008), researchers have found that there is a difference in fruit and vegetable intake by race and ethnicity, as African Americans consume less than the white population (p. 1883). Current literature suggests that adequate fruit and vegetable consumption is associated with a lower risk of some of the main causes of mortality in the United States.

\section{A Snapshot of Louisville}

Louisville Mayor Greg Fischer's Healthy Hometown Movement believes the food system in Louisville is too important to be ignored or to be allowed to operate without critical input from citizens and advocates alike (Jennings, 2011). As national trends show an increase in diet-related illnesses such as Type 2 diabetes, heart disease, and obesity (State of Food, 2010, p.3), many of the same illnesses plague the African American community in Louisville (State of Food, 2010, p.3). In West Louisville, an area 
considered to be one of Louisville's food deserts, "37\% of residents report having high blood pressure, $74 \%$ report being overweight or obese, and $12 \%$ report having diabetes" (State of Food, 2010, p.3).

Farmers and vendors are valuable to Louisville communities. Their markets and Fresh Stops are important to diets and the economy. Farmers and vendors can provide information on dietary changes that can positively impact disease risk and illnesses (Finke \& Huston, 2003, p. 301). These suppliers also learn where needs are the greatest, in order to make fruits and vegetables more accessible. In Louisville, there are four main types of local vendors: Community Farm Alliances (CFAs), famers' markets, Fresh Stops, and Healthy in a Hurry Corner Stores. Each of these is briefly discussed below.

\section{Community Farm Alliances}

Since 1985, the Community Farm Alliance (CFA) has been building positive relationships between farmers, consumers, legislators, and communities. Members of the organization are a diverse group of urban farmers and non-farmers who help bring a critical public voice to policy makers. The CFA also develops community-based projects that directly improve communities and can be used as models for public programs and policies (communityfarmalliance.org, 2012).

The CFA (2007) believes that all citizens have the right to access quality, healthy, affordably priced foods in sufficient quantities. In addition, the CFA (2007) also accepts that small, independent farmers of Kentucky are the most reliable, efficient and careful producers of food for Kentuckians. 
According to the CFA, 70\% of Jefferson County's African American population resides in West Louisville and East Downtown (Community Farm Alliance, 2006). With an average household income of $\$ 16,054$ and a poverty rate of $38 \%$, many residents are faced with choosing the most convenient and affordable meals that are designed to last. Those meals may not include the USDA dietary recommendations of fruits and vegetables (Community Farm Alliance, 2006). These residents also suffer from an unequal distribution of supermarkets and the lack of vehicle access. The CFA also indicates that people with the least amount of money live in areas with the worst food options and many of them cannot drive anywhere else (Community Farm Alliance, 2007). Food access matters, and with more access to healthy foods, more families throughout Louisville will have the opportunity to lead healthier lives.

\section{Farmers Markets}

In 2007, the number of existing farmers' markets in Louisville was 17 (State of Food, 2010, p. 4). By 2009, there were 27 farmers' markets operating throughout the city (State of Food, 2010, p. 4). Louisville Metro Government currently lists 22 farmers' markets locations (Louisvilleky.gov, 2012, Farmers' Markets Locations). The Gray Street Farmers' Market and Phoenix Hill Farmers' Market are located in East Downtown. In West Louisville there are three farmers' markets; the California Neighborhood Farmers' Market, Old Louisville Farm Works Market, and Rowan Street Farmers' Market. The farmers' market is one of the oldest forms of direct marketing by small farms (Local Harvest, 2011). Farmers and vendors gather once or twice a week at an appointed location to sell their fresh fruits and vegetables. Some of the farmers' markets 
provide entertainment while others provide produce samples. According to Local Harvest (2011), local fresh farmers' markets have become a favorite marketing method for farmers throughout the United States.

\section{Fresh Stops}

Fresh Stops began in 2005 as a joint initiative of the New Agrarian Center (NAC) and the Ohio State University Cooperative Extension (fourthavenue.us). The goal of the Fresh Stop was to build a more just and sustainable local food system in Northeast Ohio and Louisville, while increasing access to local foods. New Roots, Inc. began the Fresh Stop Project in 2009 (New Roots: Fresh Stops, 2011, newrootsproduce.org). New Roots offers individuals and families the opportunity to purchase a weekly box of affordable and fresh produce. In 2009, New Roots served approximately 170 families. Produce shares are ordered one to two weeks in advance, and with each share there is a newsletter with recipes and information from farmers (New Roots: Fresh Stops, 2011, newrootsproduce.org). Community members have the opportunity to buy a box of local, fresh produce each week that they pick up at one of three Fresh Stops (Louisville Metro Government, 2011). These food shares or boxes are offered in one size and cost consumers $\$ 12.00$ for consumers who receive Electronic Benefit Transfer/Food Stamps or are low-income eligible. All others must pay $\$ 25.00$. Each share or box can feed two to three people produce for an entire week for a low cost and EBT/Debit cards are accepted. Currently, the three Fresh Stops operating in Louisville are within churches located on Preston Highway, West St. Catherine Street, and in the Shawnee neighborhood. 


\section{Healthy in a Hurry Corner Stores}

As one of the most innovative changes to the Healthy Hometown Movement, the Healthy in a Hurry Corner Stores initiative was launched in 2009 (State of Food, 2010, p. 5). The initiative aimed to increase the access and availability of fresh foods by providing technical and financial support to corner stores in low income neighborhoods. The Healthy in a Hurry Corner Stores initiative makes it possible for grocers in neighborhoods known as food deserts to carry fresh produce and other healthy foods that might otherwise not be available (Louisville.gov, 2011). According to Harrar (2011), within a year of the movement's start, the number of African Americans in downtown Louisville who ate at least five produce servings a day rose $20 \%$. To date, there are six locations in West Louisville and East Downtown that sell subsidized produce in the neighborhoods relevant to this study: Shawnee Market, Parkway Food Mart, Farm Boy Food Mart, Webb's Market, Happy Food Mart, and Curtis Market (Louisvilleky.gov, 2011, Healthy in a Hurry Corner Stores). There is a seventh location in the Berrytown neighborhood of Louisville's East end that is not relevant to the current research.

\section{African American Views on Access to Healthy Foods}

Everyone should be able to make affordable healthy food choices. "There are many options for improving healthy food access, each with a unique set of advantages to residents and community health" (localharvest.org, 2011). Purchasing fruits and vegetables at a farmers' market is commonly reported by African Americans. According to Harrar (2011), “one consumer reported that before the Healthy in a Hurry initiative was launched, the only produce she could find was withered, moldy, and expensive." 
After the Healthy in a Hurry Corner Store "opened in her local dollar store," she started to buy salad items, fresh fruit to serve as snacks, and "she planned time to cook" rather than buying prepared food (Harrar, 2011). She continued to say that her children never ate that way (consuming fruits and vegetables) before but now she sees how much better they feel.

\section{Consumer Satisfaction \& Interaction}

Balcazar et al (2006) suggests that in general, the majority of African American consumers are satisfied with several dimensions of the farmers' markets, including the overall cleanliness, location, variety, price, and quality of produce. In addition, when comparing the farmers' markets to local stores in terms of access to fresh produce, about twice the number of residents were satisfied with the farmers' markets than with the local stores (Balcazar et al., 2006).

Consumers interact with each other on a social level at farmers' markets. Some consumer social interactions, such as enjoying the market, talking with farmers about seasonal products, and making a trip to the market a family event, are significant and positive influences on spending (Hunt, 2007). Through direct farmer/consumer relations, farmers indicated a willingness to reduce chemical inputs to meet the consumer's demands (Hunt, 2007, p. 54). With the increased consumption of fresh fruits and vegetables over the years, farmers' markets are seeing success. Previous surveys and literature indicate that consumers patronize farmers' markets primarily for the high quality of fresh produce and competitive prices (Hunt, 2007). 


\section{Perspectives of Vendors and Farmers}

The produce that farmers bring to the famers' markets and Fresh Stops is also affected by the composition of the consumer population, lifestyle, income, and convenience. Demographic factors can also alter consumption trends. Farmers and vendors must understand the attitude preferences and characteristics of the consumers who shop at the markets. Through interaction and evaluation, farmers and vendors are better able to meet the demand of the consumer (Hunt, 2007). The perceptions and experiences that farmers and vendors share may differ from those of the consumer. Therefore it is important to understand the suppliers' perspectives. 


\section{THEORETICAL FRAMEWORK}

The farmers' markets, Fresh Stops, and Healthy in a Hurry Corner Stores are initiatives to encourage and maintain healthy eating habits in areas with limited access to fresh produce. There is strong evidence that eating a diet rich in fresh fruit and vegetables is vital for health and well-being (Egan, 2011). A nutritious diet also decreases African American diet-related health disparities and limits risks for many negative health conditions. The fact that African Americans do not consume the recommended fruit and vegetable servings is clearly an issue that relates to access and availability, and has also been conceptualized as a cultural phenomenon in some instances.

Social interaction is not a new phenomenon. Building bonds and developing relationships with others has always existed. The only concept that has changed over the course of time is the way such bonds and relationships are initiated. While interaction is a normal part of everyday functions, the level of interaction may vary between individuals. The process of meeting and greeting, or building relationships, is often complex at times even though it is a process that is repeated frequently throughout life.

This study utilizes the social penetration theory developed by Altman and Taylor (1973) as a guide. This theory is based on one premise; as relationships start to develop, individuals begin to reveal more about themselves. Although this concept may seem 
simplistic, this theory plays a huge role in how the world functions socially and contributes substantively to the field of interpersonal communication (Spring, 2002).

When a consumer visits the farmers' markets, Fresh Stops, or Healthy in a Hurry Corner Stores they create an opportunity for exposure to the seller. This exposure allows both parties to discover more about one another and to reveal information. Altman and Taylor (1973) examined how individuals develop a personal bond with another person. In addition, they developed a pattern that is divided into four stages of relational development, which are applicable and relevant to this study. The first stage is classified as the orientation stage. In this stage, both parties play it safe by keeping conversations to a minimum. The norms of appropriateness and standards of social desirability are followed (Spring, 2002). For example, the consumers, farmers, and vendors are only generating small talk. The next stage is classified as the exploratory stage. The consumers, farmers and vendors start to interact more as they begin to reveal more information about themselves to one another. The consumer and the seller (farmer/vendor) start to express personal attitudes as they begin to feel their way forward (Spring, 2002). Consumers expose vulnerabilities, so trust has to be developed along the way. This stage is usually when the casual friendship is formed. The third stage, the affective stage is when the vendors and consumers are more intimate (Spring, 2002). They are comfortable and accepting of one another now so it is acceptable to discuss personal and private matters because the trust has now been established. For example, when there are single parents and families who are struggling with unfortunate situations, details may surface as the consumer indicates they are making sacrifices to ensure that their child is eating healthy. The final stage is classified as the stable stage. At this stage 
in the relationship, the vendors and consumers can predict each other's actions. For example, the vendor can usually predict which fruits and vegetables the consumer may enjoy or prefer if another selection is not available. It is also important to discuss a final component of theory developed by Altman and Taylor (1973), known as depenetration. This stage occurs when a relationship between the farmer or vendor and the consumer terminates. These relationships can end for various reasons.

There is constant interaction going on at the farmers' markets and Fresh Stops. The vendor must provide the consumer with relevant information that will allow the consumer to make decisions about fruits and vegetables. Research shows that changing behavior is a challenging process but it is an essential component of health delivery and health promotion (Sobel, 2011). Farmers' markets, local Fresh Stops, and Healthy in a Hurry Corner Stores are primarily focused on changing accessibility to allow for behavior change.

In order to examine the determinants of fruit and vegetable consumption within the African American population, it is useful to begin with accessibility and availability. Ruel, Minot \& Smith (2005) have found that consumption patterns are determined by a combination of factors: the location of markets that sell fresh produce, whether or not the produce is available, and the overall quality and price of produce. Preferences are based on the composition of the household and the knowledge of members, habits, cultural norms, and personal experiences. Thus it seems important to study how farmers and vendors play into this scenario. 


\section{Research Questions}

The goal of this study was to learn and understand how farmers and vendors communicate with African American consumers. It was also important to understand what suppliers could do to better market their products, while potentially serving the health needs of the African American community. The research questions for this study included:

RQ1.) How are vendors interacting with their customers in West Louisville and East Downtown, and how do these interactions impact fruit and vegetable consumption?

RQ2.) How, if at all, do local vendors acquire and adapt consumer information to influence sales? Do vendors perceive this has an impact on the consumers' health? 


\section{METHOD}

\section{Introduction}

This study examined vendor experiences within the environments of the farmers' markets, Fresh Stops, and Healthy in a Hurry Corner Stores in West Louisville and East Downtown using in-depth interviews. A qualitative approach was used to understand the personal experiences of farmers and vendors within the farmers' markets, Fresh Stops, and Healthy in a Hurry Corner Stores. Although an effective research tool, it would be difficult to use quantitative strategies such as surveys or experiments to understand how vendors and consumers communicate. By incorporating the qualitative method of indepth interviews, the farmers and vendors were able to share their personal experiences and perspectives within the farmers' markets, Fresh Stops, and Healthy in a Hurry Corner Stores.

\section{Study Sample}

$I R B$. For the purpose of this study it was necessary for the researcher to obtain approval from the Institutional Review Boards, or IRB. This committee is mandated by federal regulation that reviews and monitor plans for research and evaluations involving human subjects (Louisville.edu/research/humansubjects). It is important to keep in mind that this committee not only protects the study participants from unethical methods or 
inappropriate questions, but also protects the researcher and their program in the event that someone does not like part of the study (umich.edu).

After the approval was obtained, the researcher worked with the co-director on the thesis committee to discuss possible contacts for the study. The co-director also provided the researcher with information on upcoming events where possible contacts would be present, allowing for a brief face-to-face introduction. The researcher developed a list of potential participants and obtained contact information. Ten potential participants were first contacted by telephone and were presented with the opportunity to be a part of this study, while one potential participant was first contacted by electronic mail and was presented with the same opportunity. The researcher left voice messages for three of the potential participants explaining the purpose of the call and study. The researcher did not offer or guarantee participants any benefits or incentives. It was understood that this study was based completely on the participant's willingness to help the University of Louisville.

Participant Selection. The sampling for this study was not only voluntary but was also convenient. There were seven potential participants who were available for a brief conversation when contacted by phone. These potential participants were asked if they were directly involved with the farmers' markets, Fresh Stop Stops, or Healthy in a Hurry Corner Stores. In addition they were also asked if they experienced interaction with African American consumers at the farmers' markets, Fresh Stops, and Healthy in a Hurry Corner Stores. If the potential participant suggested an interest or a willingness to participate, an interview time and date were scheduled while the potential participant was on the telephone. The interviews were scheduled to occur as a telephone interview or in 
person at the participants' organization or at a mutual location allowing flexibility for the participant.

Sample Description. The sample of participants for this study included a total of 8 adults; 3 males and 5 females. There was one African American male and one African American female. The remaining participants were Caucasian. Each of the participants worked directly with the farmers' markets, Fresh Stops, Healthy in a Hurry Corner Stores or provided fresh fruits and vegetables to the markets. The participants had frequent experience and interaction with African American consumers.

Data Collection. Informed consent was obtained prior to each interview. For the interviewees who participated via telephone interview, a copy of the informed consent form was sent by electronic mail. The researcher then read a printed script to the participant in order to simplify the purpose of the study and to reveal expectations of the participant. Two of the interviews were conducted in person while the remaining six interviews were conducted by telephone. All eight interviews lasted between 17 and 81 minutes. On average, each interview was about 45 minutes long. The total time for six of the interviews included the reading of the informed consent script, which required an average of approximately three minutes for each telephone interview. Each participant was also informed that the interviews would be audio recorded and were asked if they had any questions or concerns. In addition, each participant was asked a second time if it was acceptable to continue with the interview in order to ensure their approval of recording the interview.

Interview Protocol. As noted earlier, the interviews were either conducted in person or by telephone. Seven of the interviews were recorded on a digital recorder 
while one interview was recorded on a voice application with iPhone technology. The interview guide was used to provide the researcher with information to ask the participant in order to satisfactorily evaluate the research questions. The interview guide also allowed the participants to respond to the questions by expressing their own thoughts and opinions.

Interview Structure. For the purpose of this study, the researcher designed two interview guides: a guide for farmers and a guide for vendors. Although the guides were designed for different participants, they greatly resembled one another. The guides were constructed with questions that were organized categorically. This particular organization allowed for questions to be skipped if the participants had unknowingly already answered a question in a previous response. This structure also allowed the researcher to ask follow-up probing questions that may not have been included in the original interview guides as warranted by the participants' responses. The interview questions allowed the participants to revisit their experiences at the markets and share those experiences in detail. The participants were asked to discuss their social interactions with customers and to share information that they had heard at the farmers' markets, Fresh Stops, and Healthy in a Hurry Corner Stores. At the end of the interview, the participants were asked if they had any questions or concerns to discuss with the researcher.

The interview guide for the farmers consisted of questions that focused on the farmers' background. The farmers also were asked to discuss their land and the types of crops they grow. The interview guide also contained questions that pertained to locations at which the farmers sold produce, the farmers' involvement at the farmers' markets, 
Fresh Stops, and Healthy in a Hurry Corner Stores, and the interactions that take place at these locations. The relationships with consumers and the farmers' overall perceptions and feedback were also included in the guide. A full interview guide that consists of all of the questions can be viewed in the Appendix.

The interview guide designed for the vendors and organizers closely resembled that of the farmers' guide. While this guide focused more on the participant and his/her involvement with the farmers' markets, Fresh Stops, and Healthy in a Hurry Corner Stores, questions varied from participant backgrounds to duties specific to his/her position. Another part of the guide was also based on witnessed and experienced social interactions. The guide also consisted of questions that were focused on the participants' perceptions of how African American consumers respond to their products and information. In addition to the full farmers' guide, there is also a full guide for the vendors in the Appendix.

Data Analysis. The researcher listened to the interviews on multiple occasions and all interviews were transcribed verbatim. The total time for the digital audio recordings was five hours and 45 minutes while the total number of pages of transcripts was 98 .

Once all of the interviews were transcribed, the information was then saved and opened as a new project in QDA Miner (Provalis Research, 2011, QDA Miner v4), a qualitative data management and analysis program. The data were analyzed again on several occasions by listening to the audio recordings and comparing those recordings with transcribed documents for accuracy. During this process, each participant was assigned an identification number based on the last two digits of the digital audio 
recording file number. Table 1 lists each participant and provides information such as the participant's identification number, gender, and race. In addition, each participant's affiliated organization is included. Participants, who provided produce to more than one location, were considered suppliers for the purpose of this table. Classification for each participant is listed as vendor, farmer or chef.

\section{Table 1.}

\section{$\underline{\text { Participant Information }}$}

\begin{tabular}{|lllll|}
$\begin{array}{l}\text { Participant } \\
\text { Identification } \\
\text { Number }\end{array}$ & $\begin{array}{l}\text { Participant } \\
\text { Organization/ } \\
\text { Role }\end{array}$ & $\begin{array}{l}\text { Participant } \\
\text { Gender }\end{array}$ & $\begin{array}{l}\text { Participant } \\
\text { Race }\end{array}$ & $\begin{array}{l}\text { Participant } \\
\text { Classification }\end{array}$ \\
\hline 49 & HIHCS & Female & C & Vendor \\
50 & FS & Male & C & Vendor \\
51 & FS & Female & C & Vendor \\
52 & S & Female & C & Vendor \\
55 & S & Male & AA & Farmer \\
57 & CF & Male & AA & Chef \\
60 & FS & Female & AA & Vendor \\
62 & S & Female & C & Farmer \\
& & & & \\
\hline
\end{tabular}

Note. HIHCS = Healthy in a Hurry Corner Stores; FS = Fresh Stop; $\mathrm{S}=$ Supplier; $\mathrm{CF}=$ Chef; $\mathrm{C}=$ Caucasian; $\mathrm{AA}=$ African American;

A thematic analysis was conducted based on Owen's criteria (1984) by capturing the most important elements and recurring themes derived from the interviews. According to Owen's criteria (1984), recurrence occurs when similar meanings occur throughout in depth interviews. The second criterion, repetition, refers to the repeated use of words, concepts and phrases. The selected themes met Owens's criteria and provided a better understanding of the research questions that were presented (Owen, 1984). The researcher analyzed each interview individually and coded the data for the initial significant themes. Once each individual transcript was analyzed and coded, the 
researcher began to look at the interviews as a whole. Any keywords, phrases, concepts or other significant data that recurred were then organized into a larger category. This organization helped to reduce the number of total themes and minimized redundancy across the large amount of raw data. The researcher then reexamined the categories and its contents in order to guarantee that each category consisted of the most significant data relative to the study. The researcher also wanted to be sure that each theme was consistent and recurring. 


\section{RESULTS}

The data initially revealed several concepts and patterns that were relevant to the research questions. However, many of these patterns were consolidated or classified under one of four main themes. These four themes included perceptions of empowerment and sense of community, accessibility and acceptance, education, and excitement and fun. The researcher then analyzed the research questions again and decided to condense the four main themes into two distinct categories that were more appropriate in terms of serving the research questions. The main two categories were Social Interaction and Factors Influencing Consumption. The researcher then created a final category, Additional Contributing Themes, to note themes that were less recurring but also contributed to the study. The Social Interaction category contained the themes of empowerment and sense of community and excitement and fun. The remaining themes, accessibility and acceptance, and education fit within the Factors Influencing Consumption category. Themes such as organizational pride, comparative views of farmers' markets, Fresh Stops, and Healthy in a Hurry Corner Stores among participants, children, funding, influences by the chef, and disaffiliation were assigned to the Additional Contributing Themes category. Although some of the themes within this particular category could also fit into one of the other categories, it seems more appropriate to discuss them within the final category due to their weaker existence in the data. Below, the researcher examines and discusses these three significant categories and the relevant themes within each. 


\section{Social Interaction}

When describing what they see at farmers' markets, Fresh Stops, and Healthy in a Hurry Corner Stores, participants say they can easily identify first-time consumers because these individuals are orienting themselves with the location and available produce. Participants also describe some of the activities they do to orient themselves to the customers. They begin initial conversations with consumers but these conversations are kept short during these first few moments and visits. As classified by Altman and Taylor (1973), these initial conversations characterize actions taking place during the first stage, the orientation stage. The participants also indicated that as they are exposed to consumers more frequently, they start to build relationships and bonds with certain consumers. The development of such relationships and bonds characterize the exploratory stage as participants describe how consumers start to reveal personal information and begin to ask questions allowing them to obtain beneficial information needed to make healthy choices. Participants believed their efforts at developing relationships pay off as some consumers repeatedly return to the store to purchase fresh fruits and vegetables. Participant 49 (a Healthy in a Hurry Corner Stores vendor) described the relationship between some Healthy in a Hurry Corner Stores owners and consumers as being very intimate as some owners allow consumers and their children to make purchases on credit if they do not have the money to purchase fresh fruits and vegetables at the time. Actions as such characterize the third stage, the affective stage, according to Altman and Taylor (1973). The participants also provide details that characterize the fourth stage, the stable stage, when they describe adding alternate fruits and vegetables to the boxes of consumers who attend the Fresh Stops. For example, if 
certain items are not available, they choose other types of fruits and vegetables that may be appealing to a particular consumer based on what they know about their preferences. The participants added that there may be brief conversations about the newly added items.

In the environments of the farmers' markets, Fresh Stops, and Healthy in a Hurry Corner Stores, the participants confirmed that consumers interact with one another. The participants also shared details about consumers' involvement in activities offered during particular events. The first theme the researcher noted was a theme of empowerment and building a sense of community. This theme emerged when the participants were asked about how they believed the markets and stops help the residents and community of West Louisville and East Downtown. The general agreement among all participants indicated farmers' markets, Fresh Stops, and Healthy in a Hurry Corner Stores are all about connecting people together and building relationships. Participants also suggested that the locations provide an outlet or serve as a meeting place for many of the African American consumers. Participant 51(a Fresh Stop vendor) said, "Some people call the Fresh Stop their church because some of them work on Sunday and they can't go to church so they'll say 'Well, Thursday night, that's my church.'" This particular response implies that Fresh Stops provide the African American consumer with a level of fellowship akin to attending church on Sunday mornings. In response to the same question, Participant 50 (a Fresh Stop vendor) stated, "I have found that it brings community together." A few moments later in the interview, Participant 50 also went on to state: 
There's [sic] just a lot of friendships being made and things like that connection with people and so that's a good thing. Just whenever you can connect with get[ting] people to connect with people that's a good thing and then I think one of the big things, too, is that if we can do this, somebody said that you know what else can we do? So it empowers people too.

These statements provided by the participants are significant because they show that participants perceive farmers' markets, Fresh Stops, and Healthy in a Hurry Corner Stores as actually bringing people together who share the same interests in food. In addition, the actions described and information provided by participants reflects the stages developed by Altman and Taylor (1973). From the perspectives of farmers and vendors, consumers are interacting with one another in addition to interacting with the farmers and vendors, forming new and maintaining existing relationships while purchasing fresh produce. Participant 60 (a Fresh Stop vendor) responds in reference to the Fresh Stops:

I think it's helped in just creating a deeper sense of community because not only are they getting access to healthier local food; they enjoy the fellowship of it. We come together every other week. People see people they haven't seen in years. It's a very social setting. They're coming together in the sense of food. It is clear that a sense of community is created within these locations. Further, this research shows that one must consider the community as a whole. Consumers who live in the community are able to.meet and greet friends and neighbors in an environment in which they feel safe. In addition, consumers are able to share common interests about food. The farmers and vendors believed interactions among consumers themselves had 
some impact on consumption because the consumers share hints and tips about produce with each other. The perspectives provided by the farmers and vendors suggest that as farmers, vendors, and consumers move to later stages of interaction, they learn more about what others are doing and social desirability develops.

Although the particular question which generated such responses is focused on how the farmers' markets, Fresh Stops and Healthy in a Hurry Corner Stores benefit the residents of West Louisville and East Downtown, the emerging theme of empowerment appears to be a more spiritual theme. The fact that Fresh Stops are located within churches presents a divine sense of comfort. While participants suggest that they find volunteering at the Fresh Stops spiritual, they also expressed beliefs that their efforts have an impact on the mindset of the consumers. The participants believe that if consumers can have a Fresh Stop in their community and watch it be successful, then they as consumers might be empowered to do more. Participant 50 (a Fresh Stop vendor) indicated that residents feel and believe they are able to take on the next challenge their community is facing, illustrating a sense of empowerment. Participants felt that these initiatives are bringing positive changes to the community.

Another important theme that the researcher identified in the category of Social Interaction is that of excitement and fun. Collectively, participants agreed the atmosphere of the farmers' markets, Fresh Stops, and Healthy in a Hurry Corner Stores was exciting and fun. Participant 62 (a farmer) stated that it was "neat and exciting" and that she was in awe during her first visit at a market. Other participants shared the fact that they could sense some consumers' anxiousness and excitement during their first visits. In the interviews, participants also identified food as another reason for 
excitement. The participants agreed that consumers are excited when they come in and see all of the beautiful food. Participant 50 (a Fresh Stop vendor) talked about how the Fresh Stop was an exciting experience:

I think healthy food can be tasty and good and affordable and it's exciting there. They just walk in and the smell of the food and everything and it's the new smell and it's the food so they're excited about the quantity that they get for the price. They get a good amount of food. They're excited just to try new things and new recipes.

Participant 49 (a Healthy in a Hurry Corner Store vendor) explained that Healthy in a Hurry Corner Stores usually have two press conferences each year, which are scheduled during a new store grand opening. The press conferences are a big extravaganza because they bring publicity to the store location and shed light on the efforts of the Healthy in a Hurry program. From her perspective, the new store openings are a big deal to the residents and the consumers. Participant 49 explained that Louisville mayor, Greg Fischer, is usually present at these press conferences, in addition to Congressman John Yarmouth, and Steve Tarver, Chief Executive Officer of the Louisville YMCA. There are fun activities for the children such as a moon bounce, which is a giant inflatable play structure that children like to jump in. Participant 49 also revealed the secret to her success with children at these events. She cleverly encourages children to consume the fresh fruits and vegetables that are available that day. Participant 49 stated the following:

So at one of our openings we had the mobile unit with the moon bounce which kids love to go on those things, right? So we set up a sneaky system where we 
wouldn't let kids go into the moon bounce until they tried a new fruit or vegetable at the sampling table...They got a little YMCA silly band if they sampled something and that silly band allowed them to get up in the moon bounce so that was a lot of fun. It connected the fun activity with got to try something [sic] new you might like it.

This plan of action, as described, allowed children the opportunity to accept and welcome new fruits and vegetables in a fun and encouraging environment.

A third theme identified for the Social Interactions category is defined as building friendships and relationships. Community is all about building relationships and friendships. According to Participant 49, the Healthy in a Hurry Corner Stores try to provide more of a family-friendly environment because the aim of their program is to target families who will build relationships with the store owners and continue to purchase fruits and vegetables at those locations. While most people stop by these stores to quickly grab a snack, Participant 49 suggests the Healthy in a Hurry Corners Stores strive to change this behavior. Participant 49 said:

I think it helps the store owners [to] build relationships with their customers. I think just from what I've seen the relationships are stronger when you have that clientele coming in than when you have people coming in for like a quick grab of a pack of cigarettes or a pack of beer. Like those people aren't really building a relationship with the store. It's the people who do their grocery shopping there who send their kids to pick up a couple of things for dinner beforehand.

Participant 49 explained the importance of having families stopping by the Healthy in a Hurry Corner Stores to purchase fresh produce. From her perspective, the relationships 
established between the store owners and the consumers are unique because there is a sense of trust and the consumer now depends on the owner for healthy food choices. This participant believed Healthy in a Hurry Corner Stores are now trying to establish a more welcoming and family-friendly environment.

The farmers and vendors interact with consumers on various levels. Even before some of the famers' markets, Fresh Stops, and Healthy in a Hurry Corner Stores opened, participants discussed how they used the old-fashioned method of going door to door to meet and interact with residents. Participants revealed that, for the most part, residents were very welcoming and accepting of the vendors' presence. Not surprising, one or two residents disapproved of the cause and closed their doors without further discussion, but the majority were interested in what the participants had to say. The farmers and vendors have also turned to technology with the hope of informing consumers about options and events. Some of the famers' markets and Fresh Stops have Internet websites and social networking pages such as the popular Facebook and Twitter. However, all of the participants agreed that word of mouth seems to be the most effective and most popular form of communication among vendors when trying to promote new fruit and vegetable marketplaces. They indicated that they rely on word of mouth advertising and promotion because they perceive that many residents and consumers lack consistent Internet access at home and that they may not be able to obtain information via the Internet as reliably as consumers in other neighborhoods.

At the farmers' markets, Fresh Stops, and Healthy in a Hurry Corner Stores, the participants indicated that the interaction is strong between the vendors and consumers. For the most part at the famers' markets and Fresh Stops, someone is always stationed 
near each fruit and vegetable so vendors/suppliers are able to provide consumers with information about the produce. When asked what consumers are talking about with farmers and vendors, the respondents had different answers. First, consumers ask why the farmers' markets, Fresh Stop, or Healthy in a Hurry Corner Store is in the community. The participants also mentioned that consumers want to know about the fresh fruits and vegetables and often question the prices. Participant 57 (a chef) expressed that consumers also voice concerns and questions about alternative preparation methods and the length of time for preparing specific vegetables.

While the markets and stops lack an onsite farmer all of the time, Participant 49 (a Healthy in a Hurry Corner Store vendor) discusses the difference in a conversation when a farmer is present as follows:

There's certainly a different kind of conversation going on between a person buying directly from a farmer and that is a very good and important conversation to have. We struggle to get farmers in Louisville. We struggle to get farmers to go into West Louisville because they don't believe that the buying capacity is there for their time so they'd rather go to one of the bigger more established farmers markets that's already out there and actually make money. Yeah they work really hard and they only have a couple hours to sell it each week...There are very different conversations and I think... when it comes to the farmers' market and talking directly with the farmer, buying your produce directly from the farmer, one of the huge benefits is that you're a little more in touch with the land and really thinking about where your food comes from. Which is what people often ask us; why we don't do local food in the corner stores and part of 
that is one of the biggest reasons is because that first off it's difficult to get local foods to the corner stores but that is a separate issue.

Each market is unique in terms of the conversations and interactions that occur between providers and consumers. Farmers indicated that they rarely are able to attend the markets and shops in person. At the farmers' markets and Fresh Stops, access to a farmer in person may be very limited. Participant 62 (a farmer) expressed that farmers have their work cut out for them. They are occupied with their land and making sure that crops are growing so they are able to provide markets and shops with fresh produce. Participant 62 (a farmer) shared how she felt when she experienced her first interaction with actual consumers. She described how she felt like a hero. She believed consumers were very accepting of her and also thanked her for her food. She said this moment was when she realized how big an impact that she was making in their lives.

The participants believed consumers who continue visiting the farmers' markets, Fresh Stops, and Healthy in a Hurry Corner Stores are presented with the opportunity for their relationships with the famers and vendors to blossom into something unique and special. Participants also discuss how some Healthy in a Hurry Corner Store owners allow children to come in and purchase items on credit indicating that trust has obviously been established. The participants perceived that farmers' markets, Fresh Stops, and Healthy in a Hurry Corners Stores truly provide a life changing experience for the consumers. 


\section{Factors Influencing Consumer Purchasing Decisions}

There are several factors that influence how much produce is sold at the markets and Fresh Stops. The farmers and vendors at the farmers' markets, Fresh Stops, and Healthy in a Hurry Corner Stores interact with many different populations. While some participants differed on how they adapted to the various populations, the bottom line was that they all talked about consumers coming to the markets and stops for the same reasons: produce, fellowship, and convenience. Participant 49 (a Healthy in a Hurry Corner Store vendor) discussed how Healthy in a Hurry Corner Stores send out surveys

to consumers. Some of the questions on the surveys ask the consumers about the types of produce that they would like to see added to the existing items in the stores. The farmers' markets, Fresh Stops, and Healthy in a Hurry Corner Stores try to meet the specific needs of consumers because they understand how some specific items can be a part of the population and culture.

As with any type of retail market or business of providing goods to others, the aim is to sell. The vendors involved in the markets and stops want consumers to buy their products and to spread the word so others will consider purchasing from these stores. Although sales are the overall goal for the participants, the participants indicated that it is about more than just selling produce. Participant 50 (a Fresh Stop vendor) described the farmers' markets and Fresh Stops as being more about community and establishing friendships. Access, affordability, education and acceptance were also common themes mentioned by the participants during the interviews Table 2 lists major themes grouped into this category, plus additional factors that participants presented as having an impact on the sale and purchase decision of produce. Although these factors were not recurrent 
themes, some of the participants referred to one or all of these factors as having an influence on consumers' purchase decisions.

\section{Table 2.}

Factors That Participant Say Influence Produce Sales \& Consumption

\begin{tabular}{|ll|}
\hline THEMES & ADDITIONAL FACTORS \\
\hline Access & Taste \\
Price & Produce Familiarity \\
Availability & Preparation Time \\
Education & Willingness To Try New Foods \\
Acceptance & Quality \\
& Appearance \\
& Transportation \\
\hline
\end{tabular}

Access was an important theme during this study. Participant 62 (a farmer) stated having access to these farmers' markets, Fresh Stops, and Healthy in a Hurry Corner Stores is a "No-brainer" because she believed increasing access is important. She clearly believed access influences consumption. Participant 60 (a Fresh Stop vendor) expressed that consumers in West Louisville and East Downtown usually do not have easy, affordable access to fresh, organic, and local foods. Participant 49 (a Healthy in a Hurry Corner Store vendor) added that while some consumers want traditional and conventional foods, some want organic and some want local. She believed the farmers' markets, Fresh Stops, and Healthy in a Hurry Corner Stores allow these individualistic needs to be met with their produce and products.

Affordability is another key factor that participants identified as contributing to whether produce sells or not. Participant 52 (a supplier) described how consumers who live in these areas usually are unable to afford higher-priced produce. Consequently, 
price has a big impact on the decision that consumers make in regards to purchasing. The prices for produce can be competitive at farmers' markets, Fresh Stops, and Healthy in a Hurry Corner Stores but vendors do try to "shop the markets." Competitive shopping occurs when the vendors go out and visit other nearby markets to price produce. The vendors will then go back to their organization and compare prices to make sure that they are offering the best prices to the consumers.

Another one of the most important themes participants described as an influential factor in purchase decisions is education. Interview participants state that this emerging theme has a huge effect not only on the sale of produce but also on the choices that consumers make. Interestingly, all of the participants refer to education as being an important factor in the way in which consumers respond to the farmers' markets, Fresh Stops, and Healthy in a Hurry Corner Stores. Participant 57 (a chef) states that consumers do have expectations when visiting farmers' markets, Fresh Stops, and Healthy in a Hurry Corner Stores and when these expectations are not met disappointment can follow. This disappointment is due to a lack of produce available at the time of the visit. Participant 57 explains that some corner store owners order large quantities of fruits and vegetables which only have a three-to seven-day shelf-life. When the owners order produce 30 days out, they are throwing away money as much of the produce is inedible and must be discarded. This participant also expressed the need for both consumers and corner store owners to be educated on produce and produce storage. From this participant's perspective, store owners need proper education on how often and when to place orders to ensure that produce remains fresh. He added that owners must also know how to store the produce in the stores. In addition, this participant discussed 
that consumers must know general basic nutrition information and must know how to recognize fresh fruits and vegetables by appropriate names and classifications.

Participant 57 also mentioned the additional needs for consumers to be educated on food preparations in general, how to store fresh produce and how long they can wait to prepare the produce once they make purchases. In addition to purchase decisions, education is clearly thought to be significant to the preparation of fruits and vegetables. Participant 55 (a farmer) reflects, "A lot of it is lack of education of how to prepare and what's good for you." While expressing the imperativeness of education, this participant also mentioned that the lack of education requires the farmers and vendors to do extra things such as prepare and print recipe handouts and nutritional information so that consumers have the necessary information. Participant 55 also identified another important factor relating to the sale of produce as the demand for expediency in the United States today. As Participant 55 described, if a consumer wants strawberries at that precise moment and does not want to wait until they are in season, he or she usually does not care who provides them. Therefore, demand can be quite focused and unstable at times. It is also mentioned by the participant that the desire to cook among young consumers is simply nonexistent.

Table 3 shows produce items that participants indicated are more popular at the farmers' markets and Fresh Stops. Participants believed the popularity of certain items to be largely associated with preparation methods and cooking times. According to the participants, younger consumers seem to want produce that can be sliced and eaten with little or no effort, so participants report that salad items are usually in higher demand among this demographic. Overall, participants said that items that can be boiled or 
cooked in the microwave are the best sellers whereas items that take longer to prepare never sell out.

\section{Table 3.}

\section{High and Low Demand Produce}

\begin{tabular}{ll|}
\hline HIGH DEMAND & LOW DEMAND \\
\hline Lettuce & Greens \\
Tomatoes & Squash \\
Onions & Eggplants \\
Sweet Corn & Beets \\
Cantaloupe & \\
Melons & \\
Cucumbers & \\
& \\
\hline
\end{tabular}

Participant 52 (a supplier) acknowledged that access (the first theme discussed above) influences consumption, but went on to explain that she also believes education is a big factor. She states:

Bringing food into neighborhood situations is easier for people to access but I think that education has to follow up with that. I think there has to be more education and we have to teach our mothers and fathers how to cook again because in our areas it's easier to get a value meal for five dollars.

Participant 55 (a farmer) also explained that many patrons are younger parents who lack the cooking skills and education needed to feed their family healthy meals. Although the Fresh Stop offers food justice classes, Participant 51 (a Fresh Stop vendor) emphasized that these classes are a positive action, though not a cure. Collectively, participants agreed there must be additional education provided to the consumers. The 
participants also believed there is a need for basic nutrition information and facts so that consumers are better able to make informed choices and decisions about fresh fruits and vegetables.

A final theme related to consumption is that of general acceptance of the farmers' markets, Fresh Stops, and Healthy in a Hurry Corner Stores. Although all participants agreed that African American consumers are accepting of the food changes occurring within their neighborhood, Participant 55 (a farmer) suggested that, at times, consumers may question the purpose of the farmers' markets, Fresh Stops, and Healthy in a Hurry Corner Stores. She said consumers want to know exactly why the establishment is there. For the most part, though, participants agreed consumers are accepting of information and are willing to try new produce. Participant 55 confirmed some consumers may even come back to the market and tell the farmers and vendors that a certain preparation method was a failure and simply did not work. From the perspectives provided by the participants, consumers seem to enjoy the recipes, newsletters and food.

\section{Additional Contributing Themes}

The researcher found that several other themes emerged from the participant interviews and, though less recurring, the themes seemed valuable to the study. Pride was an additional contributing theme that was sensed as participants discussed their particular organization. When asked how they believed the farmers' market, Fresh Stops, and Healthy in a Hurry Corner Stores help the residents of West Louisville and East Downtown. Participant 51(a Fresh Stop vendor) stated: 
I don't think they [farmers' markets] help residents and I don't know if I really want to talk about Healthy in a Hurry, but I don't feel like they've been very helpful. The reason why I think Fresh Stops have been helpful and has the most potential is because of the community organizing, leadership development, and community ownership component.

She also went on to state:

I don't preferably feel like the money made or investments in these corner stores has really paid off in any tangible change... so I think...the reason why I put all my eggs in [to being] the Fresh Stops advocate... and use all my free hours to make sure that this works and continues [to be successful] is because I have seen it work... and I have seen people change.

These statements clearly indicated that she is proud of the Fresh Stops and prides herself on being an advocate due to the respect that she has for the organization. In contrast Participant 49 (a Healthy in a Hurry vendor) expressed how shaky she believed the farmers' markets have been and that Healthy in a Hurry Corner Stores have been very successful in increasing access of fresh fruits and vegetables.

As the participants discussed their organization and other farmers' markets, Fresh Stops, and Healthy in a Hurry Corner Stores, all participants provided different perspectives. A second, and inherently related, theme to be discussed is the comparative views of the farmers' markets, Fresh Stops, and Healthy in a Hurry Corner Stores expressed by the participants. Participant 49 stated, "We [the Corner Stores] are fulfilling one need. The Fresh Stops are fulfilling another very important need. The farmers' markets...are [fulfilling] another very important need." 
An additional theme, disassociation, surfaces when discussing comparative views. Disassociation could easily fit into the Factors Influencing Consumption category as well. The fact that farmers' markets, Fresh Stops, and Healthy in a Hurry Corner Stores are not collaborative, but rather function independently of one another, is a factor that can influence consumption in a negative way. Overall, though participants may have different perspectives on which initiative has been the most successful, they agreed farmers' markets, Fresh Stops, and Healthy in a Hurry Corner Stores all have different purposes.

Children were also chosen as an additional theme. Although, some of the participants' comments about children were limited, increasing fruit and vegetable consumption among children proved to be just as important to participants' overall goals. Participant 51 (a Fresh Stop vendor) stated, 'I don't think I've ever recovered from seeing all of the sickness, especially with the children that come about from eating fast and processed foods and not eating fresh food."

Additionally, the farmers and vendors also indicated that funding is a major concern. As some government support will come to an end during this study, there is a concern for maintaining success of the Healthy in a Hurry Corner Stores in the future. Participant 49 (a Healthy in a Hurry Corner Store vendor) explained that she is also working on an Association of Healthy Corner Store owners which will be a business association providing resources to the existing corner store owners and new corner store owners on how to be a healthy presence within their communities. The goal of the association is to ensure that Healthy in a Hurry Corner Stores will continue to be successful after government funding comes to an end. Some participants revealed that 
the government does not support their efforts financially. While having no government support and funding for such projects would seem like a struggle, the interviewees remained positive and considered their effort as one that simply works for the greater good of the people.

The chef is another theme to be discussed and is one that may also fit in the Factors Influencing Consumption category. Perspectives from the participants indicated the chef could possibly have some impact on consumption. Participant 51(a Fresh Stop vendor) stated, "[Consumers ask the chef] how do I cook this Chinese cabbage? What is this eggplant? ...He will not eat this. ...With the chef, there's this positive peer pressure making sure that everybody has tried what's in their baskets." Participant 49 (a Healthy in a Hurry Corner Store vendor) also shared comments about the chef by stating, "We'll do taste testing and we'll have a chef out there...making stuff with the items in the corner stores, giving out recipes and encouraging residents to try the produce." Participant 57 (a chef) also shared information about working with Participant 49 and cooking fresh produce at the Healthy in a Hurry Corner Store locations beginning in the summer months of 2012. Through the participants' perspectives, it is suggested that the chef may be a positive influence for consumers, therefore possibly having an impact on consumption. 


\section{DISCUSSION}

As reflected by the participants' perspectives in this study, the farmers' markets, Fresh Stops, and Healthy in a Hurry Corner Stores seem to be making a positive impact on the African American consumers in West Louisville and East Downtown. Although many factors influence overall fruit and vegetable consumption, participants' experiences generally illustrate that consumers do care about the concepts of eating healthy and living a healthier lifestyle. Although children were mentioned in some of the interviews, participants revealed that many single mothers in West Louisville have expressed concern that they want to make sure that their children are provided with healthy meals. These mothers seek alternative ways to prepare fruit and vegetables that will work with their schedules. In addition to learning new and healthier food preparation techniques, the participants' comments demonstrate consumers' desires to know more about the fresh fruits and vegetables.

A benefit offered by the Fresh Stops and Healthy in a Hurry Corner Stores is the chef who is on site at the location for that day preparing meals with the fruits and vegetables that are available to the residents. The chef's presence could be viewed as an additional factor contributing to consumer consumption. For the resident who never liked eggplant, he or she now indulges in the vegetable because the chef provided information on how to appealingly prepare the vegetable. Often the chef can be overlooked as being a possible contributing factor to education because generally, the 
chef is identified as only being at the location to cook. This study reveals that through the chef's interactions with the consumers, the consumers may be more likely to try new fruits and vegetables and in addition to trying different food preparation methods.

Although this study consisted of interviewing participants at each of the different establishments, not all of the participants were involved with the farmers' markets, Fresh Stops, and Healthy in a Hurry Corner Stores in the same manner. Each participant was involved with the consumers to some extent though one participant had limited interaction with them. This one participant's limited interaction is interesting due to the fact that she was an actual farmer. One might expect that farmers who supply products to the farmers' markets, Fresh Stops, and Healthy in a Hurry Corner Stores would have a substantial amount of interaction with consumers. Although some farmers have more interaction with consumers than others it is important to discuss the disappointment that participants witnessed among consumers when they realize that their farmer is unavailable. The disappointment could negatively affect the attitudes of the consumers, which could, in turn, decrease consumption. Participants believe that consumers want to put a face and body with their food because it shows that farmers care about their consumers. The themes identified in the social interaction category illustrate that it is not always about the financial part of the effort because it is about increasing access and bringing people together. Making a profit is not the only objective.

Although the farmers' markets, Fresh Stops, and Healthy in a Hurry Corner Stores' primary goals are to provide better access and availability of fresh fruits and vegetables, participants from the different establishments appear to have developed a sense of pride about their organization. This sense of pride is multifaceted. There is a 
consumer focus as organizations have pride in what they are doing for the community. The organizations take pride in helping build a sense of empowerment and community. The organizational focus is present as organizations take pride in their organizations and its functions. This sense of pride also approaches competition between the different organizations as each organization takes pride in being the best. This pride may stem from the reactions farmers and vendors get from consumers and the relationships they have developed over time with people who live in and around the stops/markets. Social interactions have progressed past the orientation and exploratory stages which implies that continuity of current initiatives is important. New initiatives would have to start back at the orientation stage. While some participants view other markets and stops as failures, or as being unsuccessful, the study indicates that participants simply will not speak poorly about their own establishment. The general agreement is that for each participant, his or her own efforts work and has been successful.

An underutilized strategy that can be put in place to increase fruit and vegetable consumption is that of unity across vendors and suppliers. As noted earlier there are many residents in Louisville who suffer from the nation's leading killers, including obesity, diabetes, and cardiovascular disease. One contributing factor to these chronic diseases is diet (Viswanath \& Bond, 2007). Farmers' markets, Fresh Stops, and Healthy in a Hurry Corner Stores could work together to provide more access to fresh fruits and vegetables for residents at risk of chronic illness. By choosing to work together and possibly develop community partnerships vendors and suppliers can keep the issue of increasing access to fresh fruits and vegetables at the forefront and strengthen current initiatives. 
There are several actions that take place in order for these markets and stops to successfully meet the goals of increasing the consumption of fresh fruits and vegetables among African American consumers. Volunteers make the fresh stops a success because they are people from the community striving to make a difference for what they believe in. Once the farmer ships the produce from his location to the markets and stops, the produce must be unloaded and set up by volunteers and organizers at the locations. There is a lot of community organizing that goes into making sure that these efforts are fully functional and maintained. The amount of work that individuals put into these efforts is truly significant because even the smallest duty from making a phone call to collecting money makes an incredible difference. Figure 1 provides an illustration of the above mentioned process that must take place in order for consumers to receive fresh fruits and vegetables at the markets and stops. 


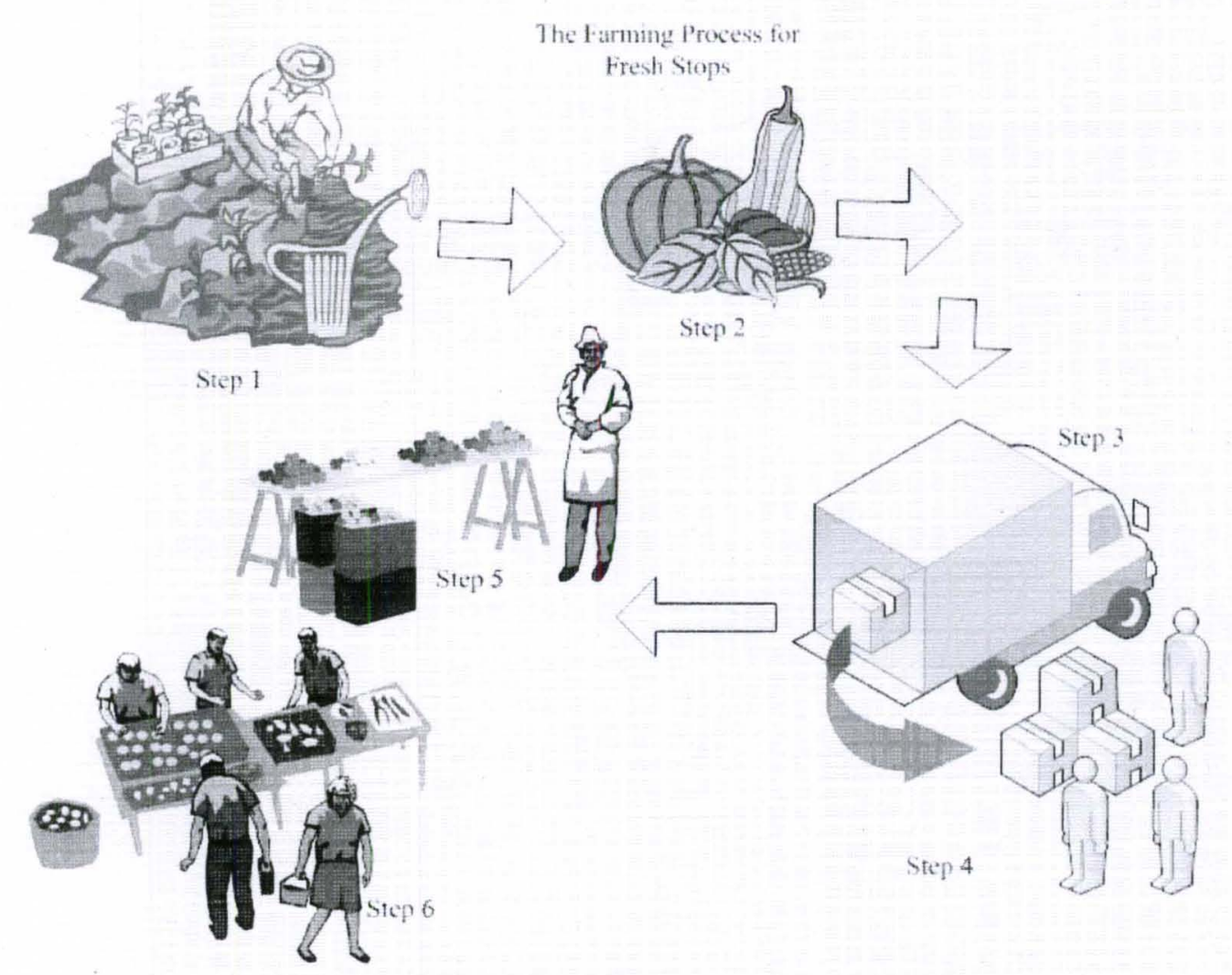

FIGURE1. The above illustration shows the steps of the process allowing farmers to transport their crops to the markets and fresh stops. The farmers plant the crops on their land and once the fruits and vegetables are ready to be picked, they are shipped to the markets and stops. The volunteers at the markets and stops help unload the truck and organize the produce at the location. Consumers then come to pick up their orders and speak with the vendors and farmers that are available. 


\section{CONCLUSION}

In conclusion, this study reveals how bonds and relationships are developed between the farmers, vendors, and African American consumers at the farmers' markets, Fresh Stops, and Healthy in a Hurry Corner Stores. By utilizing the social penetration theory developed by Altman and Taylor (1973), it was discovered that as relationships developed through the stages described by Altman and Taylor (1973), both suppliers and consumers share more information about themselves to one another. Farmers may share details about their farms and produce while consumers talk about certain fruits and vegetables that appeal to their preferences. As they become familiar with one another, trust is established and farmers and vendors are better able to provide the consumers with recommendations and suggestions about fruits and vegetables. In addition, farmers and vendors are able to encourage consumers to try new fruits and vegetables based on previous experiences and interactions.

Through this study, the participants' perspectives provide insight on the environments of the farmers' markets, Fresh Stops, and Healthy in a Hurry Corner Stores. The overall atmospheres of these locations seem to offer a fun and exciting opportunity for the visiting consumers. The interactions at these locations are viewed as being positive as people are joined together by fresh fruits and vegetables and developing a sense of community.

The importance of accessibility and availability of fresh fruits and vegetables in the low income areas throughout the West Louisville and East Downtown neighborhoods 
is also defined within this study. It was found that there are several positive themes, such as building a sense of community, which remained consistent with the farmers' and vendors' responses in regards to their perceptions of interaction among and with the African American consumers. This research study indicates that there is a positive response and acceptance form the African American consumers to the farmers' markets, Fresh Stops, and Healthy in a Hurry Corner Stores, according to the perspectives of farmers and vendors.

The study also finds that several factors influence the African American consumption of fresh fruits and vegetables. The farmers and vendors also recognized factors such as lack of education, taste preferences, and affordability. Both farmers and vendors agreed that specific knowledge of how to prepare fruits and vegetables is lacking within the African American consumers with which they interact. In addition, farmers and vendors believed consumers need more basic knowledge and education so they are better able to make informed choices about fresh fruits and vegetables, and their overall nutrition.

\section{Limitations}

The limitations of this study include having one researcher to analyze and interpret data. With only one researcher, the responses provided by participants were only subject to interpretations of that researcher. There were also eight participants of which only two were farmers. The study did not include interviews from farmers who were presently involved at farmer's markets and Fresh Stops, or actual Healthy in a Hurry Corner Stores owners. 


\section{Recommendations for Future Research and Practice}

There should be research conducted to examine consumer satisfaction on a more in depth-level with the efforts of the farmers' markets, Fresh Stops, and Healthy in a Hurry programs. Further research should be conducted to determine what local sites, if any, within the African American communities would be successful marketing channels for pushing local food movement initiatives. The salons, black churches and barbershops are often viewed as meeting places within the African American communities therefore could possibly be places for vendors to occupy in terms of reaching African American consumers.

Finally, the farmers' markets, Fresh Stops, and Healthy in a Hurry Corner Stores share the same beliefs about access to quality fresh fruits and vegetables. These organizations should reach out to one another and work together to increase access and availability of fresh fruits and vegetables; therefore having a collaborative impact on consumption. Instead of an initiative only identifying another organization as a failure or not being quite as successful, the more prosperous organization should offer suggestions and display a willingness to help those who are not thriving. The organizations could set up roundtable discussions to keep each other involved and informed on the latest consumers trends and produce. The organizations could also explore the possibilities of advertising for one another to increase consumer purchasing behavior. For example, if one vendor is closed for business on a certain day, that particular vendor could encourage consumers to go to another organization if they are in need of fresh fruits and vegetables during the time their primary location is closed. Promoting other farmers' markets, Fresh 
Stops, and Healthy in a Hurry Corner Stores could possibly increase consumer traffic, sales, and profits.

Perhaps, the organizations could collaborate on developing more food justice classes and design new educational programs which focus on basic produce information and food preparation methods. For example, one organization could be responsible for classes on Thursday nights while another is responsible for classes on Monday mornings, allowing flexibility for consumers. Sharing information and resources would be another great benefit of working together. While these are only suggestions for future research and practice, these ideas may aid the community efforts to provide access of fresh fruits and vegetables in lower income areas, which is not only limited to Louisville and the Commonwealth of Kentucky, but throughout the nation, as well. 


\section{REFERENCES}

Altman, I., \& Taylor, D., (1973). Social Penetration: The Development of Interpersonal Relationships. NewYork: Holt, Rinehart and Winston

American Heart Association. Heart Diseases and Stroke Statistics: 2009 Update At-AGlance (2009). Retrieved April 10, 2009, from http://americanheart.org/downloadable/heart/123565990943909Heart\%20and\%20 Stroke\%20Update.pdf (page 4, 17).

Balcazar, Y. S., Martinez, L. I., Cox, G., \& Jayraj, A. (2006). African americans' views on access to healthy foods: What a farmers' market provides. Journal of Extension, 44(2), 1-7.

Belle, G. (2009). Can the african-american diet be made healthier without giving up culture. The York Scholar, Retrieved from https://www.york.cuny.edu/academics/writing-program/the-york-scholar1/volume-5.2-spring-2009/table-of-contents/can-the-african-american-diet-bemade-healthier-without-giving-up-culture

Better nutrition promoting the health of African Americans. (2012). Retrieved from http://health.wellness.edietstar.com/Healthy_Nutrition/African_Americans

California Department of Public Health, (2009). African American health statistics. Los Angeles: Network for a Health California.

The center for African American health. (2012). Retrieved from http://caahealth.org Centers for Disease Control and Prevention. (2011). Obesity halting the epidemic by making health easier. Retrieved from http://www.cdc.gov/chronicdisease/resources/publications/aag/obesity.htm 
Centers for Disease Control and Prevention. (2010). The cdc guide to fruit and vegetable strategies to increase access, availability, and consumption. Retrieved from http://www.cdcph.ca.gov/

Community Farm Alliance, (2007). Bridging the divide: Growing sef-sufficiency in our food supply. Louisville: Community Farm Alliance.

Community Farm Alliance, (2006). Food justice in Kentucky. Louisville: Community Farm Alliance.

Community food compact. (2011). Retrieved from http://www.farmtocity.org/

Cowling, L. (2008). Health and dietary issues affecting African Americans. In California Food Guide (pp. 1-19). Retrieved from http://www.dhcs.ca.gov/formsandpubs/publications/

Dubowitz, T., Heron, M., Bird, C. E., Finch, B. K., Basurto-Davila, R., Hale, L., Escarce, J. J., \& Lurie, N. (2008). Neighborhood socioeconomic status and fruit and vegetable intake. American Journal of Clinical Nutrition, 87, 1883-1891.

Egan, E. (2011, June 19). Smoothie your way to health. Retrieved from http://parentsforhealth.org/opinion-smoothie-your-way-to-your-5-a-day

Finke, M. S., \& Huston, S. J. (2003). Factors affecting the probability of choosing a risky diet. Journal of Family and Economic Issues, 24(3), 291-303.

Fourth Avenue United Methodist Church. (2011). Louisville fresh stops. Retrieved from http://www.fourthavenue.us/brochure/Fresh_Stop_Brochure.doc

Harrar, S. (2011). Louisville gets healthy Woman's Day, Retrieved from http://www.womansday.com/health-fitness/diet-weight-loss/louisville-getshealthy-118784 
Human research protection program . (2007). (Master's thesis, University of Michigan) Retrieved from http://www.hrpp.umich.edu/

Human subjects protection program. (2008). Retrieved from http://louisville.edu/research/humansubjects

Hunt, A. R. (2007). Consumer interactions and influences on farmers' market vendors. Renewable Agriculture and Food Systems, 22(01), 54-66. doi: $10.1017 / \mathrm{S} 1742170507001597$

Jennings, J. Louisville Food Policy Advisory Council, (2011). Building Louisville's food policy council. Louisville: Louisville Food Policy Advisory Council.

Kung, C.H. et al. (2008) National Vital Statistics Reports: Deaths: Final Data for 2005. Division of Vital Statistics. Centers for Disease Control and Prevention. Retrieved April 07, 2009, from, http://www.cdc.gov/nchs/data/nvsr/nvsr56/nvsr56_10.pdf (Tables 3,12)

Local Harvest. (2011). Farmers' markets. Retrieved from http://www.localharvest.org/farmers-markets/

Louisville Metro Government. (2011). Fresh stops. Retrieved from http://www.louisvilleky.gov/HealthyHometown/healthyeating/FreshStops.htm Mayor's Hometown Movement, (2010). State of food: A snapshot of food access in louisville. Louisville: Congressional Hunger Center.

McGuire, J. W. (1984). Public communication as a strategy for inducing health behavior change. Preventive Medicine, 13, 299-319.

New Roots. (2011). New roots: fresh stops. Retrieved from http://www.newrootsproduce.org/fresh-stops.html 
Owen, W. F. (1984). Interpretive themes in relational communication. Quarterly Journal of Speech, 70, 274-87.

Provalis Research. (2011). QDA miner v4: Qualitative data analysis software for mixed methods research. Retrieved from http://www.provalisresearch.com

Ruel, M. T., Minot, N., \& Smith, L. World Health Organization, (2005). Patterns and determinants of fruit and vegetable consumption in sub-saharan Africa: $A$ multicountry comparison

Smith, R., (2002). Altman \& Taylor's social penetration theory: Important people in our lives. Retrieved from http:// http://zimmer.csufresno.edu

Sobel, J. (2001). Health communication theory: Creating messages that promote health and change behavior. Retrieved from http://www.dangerousdecibels.org/research/health-communication-theory/

Strauss, R. S., \& Pollack, H. A. (2001). Epidemic increase in childhood overweight, 1986-1998. Journal of the American Medical Association, 286(22), 2845-2848.

United States Department of Agriculture. (2011). Choose my plate. Retrieved from http://www.choosemyplate.gov/

United States Department of Agriculture. (2011). News and media. Retrieved from http://www.usda.gov/

Viswanath, K., \& Bond, K. (2007). Social determinants and nutrition: Reflections on the role of communication. Journal of Nutrition Education and Behavior, 39(2S), S20-S24. doi: 10.1016/j.jneb.2006.07.008 
APPENDIX A

INFORMED CONSENT

Subject Informed Consent Document

FARMER AND VENDOR CONSENT

DIET AND DISEASE PREVENTION INTERVIEW

Investigator(s) name $\&$ address:

Lindsay J. Della, University of Louisville, Department of Communication Deborah A. Potter, University of Louisville, Department of Sociology Margaret U D'Silva, University of Louisville, Department of Communication

Lisa B. Markowitz, University of Louisville, Department of Anthropology Theresa Rajak-Talley, University of Louisville, Department of Pan-African Studies

Siobhan Smith, University of Louisville, Department of Communication Latonia Craig, University of Louisville, Department of Pan-African Studies Quaniqua Carthan, University of Louisville, Department of Communication Keneka Cheatham, University of Louisville, Department of Communication Natasacha Jones, University of Louisville, Department of Communication 
Site(s) where study is to be conducted:

University of Louisville

Phone number for subjects to call for questions:

$502-852-5608$

Introduction and Background Information

You are invited to participate in a research study. The study is being conducted by Lindsay Della, Ph.D and co-investigators, Deborah Potter, Ph.D., Margaret U D'Silva, Ph.D., Lisa B. Markowitz, Ph.D., Theresa Rajak-Talley, Ph.D., Siobhan Smith, Ph.D., Latonia Craig, Quaniqua Carthan, Keneka Cheatham, and Natasacha Jones. The study is sponsored by the University of Louisville, Department of Communication. The study will take place at the University of Louisville. Approximately 12 people will be invited to participate.

Purpose

The purpose of this study is to learn about your involvement in local produce markets, as well as your knowledge and beliefs regarding diet, health and illness in your community

Procedures

In this study, you will be asked to participate in a recorded interview. The interview will take between 30 and 45 minutes to complete. If at any time during the interview you feel uncomfortable with a question you may decline to answer. You may also end the interview at any time if you feel uncomfortable. Your participation is voluntary. 


\section{Potential Risks}

There are no foreseeable risks other than possible discomfort in answering personal questions. There may also be unforseen risks.

\section{Benefits}

The possible benefits of this study include better understanding the community"s knowledge and beliefs about health and illness. The information collected may not benefit you directly. The information learned in this study may be helpful to others.

\section{Compensation}

You will not be compensated for your time, inconvenience, or expenses while you are in this study.

\section{Confidentiality}

Total privacy cannot be guaranteed. Your privacy will be protected to the extent permitted by law. If the results from this study are published; your name will not be made public. While unlikely, the following may look at the study records: The University of Louisville Institutional Review Board, Human Subjects Protection Program Office and the Government Office for Human Research Protections (OHRP), and the National Institutes of Health. To help ensure your privacy, we will store all digital voice recordings on a password protected computer and lock all printed copies of interview transcripts in a filing cabinet Dr. Della's office. 


\section{Voluntary Participation}

Taking part in this study is voluntary. You may choose not to take part at all. If you decide to be in this study you may stop taking part at any time. If you decide not to be in this study or if you stop taking part at any time, you will not lose any benefits for which you may qualify. You will be told about any changes that may affect your decision to continue in the study.

Research Subject's Rights, Questions, Concerns, and Complaints If you have any questions, concerns, or complaints about the research study, you have three options. You may contact the principal investigator at 502-852-5608. If you have any questions about your rights as a study subject, questions, concerns or complaints, you may call the Human Subjects Protection Program Office (HSPPO) (502) 852-5188. You may discuss any questions about your rights as a subject, in secret, with a member of the Institutional Review Board (IRB) or the HSPPO staff. The IRB is an independent committee composed of members of the University community, staff of the institutions, as well as lay members of the community not connected with these institutions. The IRB has reviewed this study. If you want to speak to a person outside the University, you may call 1-877-852-1167. You will be given the chance to talk about any questions, concerns or complaints in secret. This is a 24 hour hot line answered by people who do not work at the University of Louisville. This paper tells you what will happen during the study if you choose to take part. Your signature means that this study has been discussed with you, that your questions have been answered, and that you will take part in the study. This informed consent document is not a contract. You are not giving 
up any legal rights by signing this informed consent document. You will be given a signed copy of this paper to keep for your records.

Signature of Subject/Legal Representative Date Signed

Signature of Person Explaining the Consent Form Date Signed

(if other than the Investigator)

Signature of Investigator Date Signed

LIST OF INVESTIGATORS PHONE NUMBERS

Lindsay J. Della 502-852-5608

Deborah A. Potter 502-852-7983

Margaret U D'Silva 502-852-6976

Lisa B. Markowitz 502-852-6864

Theresa Rajak-Talley 502-852-5985

Siobhan Smith 502-852-6976

Latonia Craig 502-852-5985

Quaniqua Carthan 502-852-6976

Keneka Cheatham 502-852-6976

Natasacha Jones 502-852-6976

UNIVERSITY OF LOUISVILLE

INSTITUTIONAL REVIEW BOARD

Date Approved 02/28/2012 Valid Thru 02/19/2013 


\section{APPENDIX B}

\section{TELEPHONE CONSENT SCRIPT}

Hello, my name is I am calling from the University of Louisville because you previously indicated that you were interested in participating in this telephone interview. Before we get started, I will read through the consent paper you received when you gave us your telephone number. We are inviting you to participate in this research study by answering questions for this telephone interview which asks about your involvement in local produce markets, as well as your knowledge and beliefs regarding diet, health and illness in your community. Taking part in this study is voluntary. There are no known risks for your participation in this research study. The information collected may not benefit you directly; however, it may be helpful to others in your community. The information you provide will be shared with local public health officials to aid in the design of future disease prevention programs. Your completed interview will be stored at the University of Louisville. The interview will take approximately $30-45$ minutes to complete. Individuals from the Department of Communication, the Institutional Review Board (IRB), the Human Subjects Protection Program Office (HSPPO), and other regulatory agencies may inspect these records. In all other respects, however, the data will be held in confidence to the extent permitted by law. Should the data be published, your identity will not be disclosed. Taking part in this study is voluntary. By providing your telephone number for the purpose of conducting a phone interview, you agree to take part in this research study. You do not have to answer any questions that make you 
uncomfortable. You may choose not to take part at all. If you decide to be in this study you may stop taking part at any time. If you decide not to be in this study or if you stop taking part at any time, you will not lose any benefits for which you may qualify. If you have any questions, concerns, or complaints about the research study, please contact: Lindsay Della at 502-852-5608. If you have any questions about your rights as a research subject, you may call the Human Subjects Protection Program Office at (502) 852-5188. You can discuss any questions about your rights as a research subject, in private, with a member of the Institutional Review Board (IRB). You may also call this number if you have other questions about the research, and you cannot reach the research staff, or want to talk to someone else. The IRB is an independent committee made up of people from the University community, staff of the institutions, as well as people from the community not connected with these institutions. The IRB has reviewed this research study. If you have concerns or complaints about the research or research staff and you do not wish to give your name, you may call $1-877-852-1167$. This is a 24 hour hot line answered by people who do not work at the University of Louisville. 


\section{APPENDIX C \\ INTERVIEW GUIDE \\ INTERVIEW DISCUSSION GUIDE FOR VENDORS}

FEBRUARY 2012

\section{GREETING/WARM-UP (3 MINUTES)}

- Thank participant for agreeing to be part of the study

- Introduce yourself and the purpose of the study - to learn more about their perspective on the farmers' markets, Fresh Stops and Healthy in a Hurry programs and how they view their relationships with African American consumers

- As we talk, I want to know about some of your experiences with the healthy food initiatives and with African American consumers, there are no right or wrong answers, just your thoughts and opinions

- Reminder of observation - I will record our conversation just for us, so that we can later remember some of the important things that you said. When I report the findings I will not identify you or your consumers in any way, I'll simply talk about things that people said overall

\section{GENERAL INTERVIEW QUESTIONS}

1. Why don't you begin by telling me a little about yourself?

2. What organization do you work with? 
3. How long have you been working with the farmers' markets/Fresh Stops/Healthy in a Hurry Corner Stores?

4. What do you do?

5. So tell me, how did you get involved with this organization and cause?

6. Where is your office location?

7. Tell me about the different types of duties that you do in order to assist with the farmers' market/Fresh Stops and/or Healthy in a Hurry Corner Stores program?

8. What are some of the reasons you believe this program or initiative helps the residents of West Louisville?

9. How important are the farmers' markets, Fresh Stops, and Healthy in a Hurry Corner Stores locations?

10. You have been on site and have been at the openings of the new locations for these local initiatives, tell me about the experiences.

11. How are the interactions among the consumers?

12. When you witness the farmers and vendors with the consumer, what is going on?

13. What do you hear them talking about?

14. Tell me about the experiences when you visit other markets and Fresh Stops?

15. What types of interaction do you see going on there?

16. What about the difference in location? Tell me about some of the things that you notice. 
17. How do you adapt to the different populations and cultures when you visit other locations?

18. Describe any information that you tell consumers or farmers.

19. When you provide suggestions, are the consumers and farmers accepting?

20. How often do the consumers contact you and ask about the farmers' markets, Fresh Stops, or Healthy in a Hurry Corner Stores?

21. Tell me about some of the things they ask?

22. In general tell me some of the reasons why there is a need to push to provide these markets and healthy in a hurry stores?

23. How often do you hear consumers and farmers/vendors talking about eating healthy?

24. So tell me, after doing this for the length of time that you have been, what are the changes that you see within the community?

25. What are some of the health related concerns that you and the other organizers have?

26. Describe what you think is the most important diet related health concern?

27. What are your thoughts on obesity?

28. What are your thoughts on heart disease and diabetes?

\section{SHOPPERS AND MEDIA}

1. Describe the people that these initiatives and markets target.

2. Where do most of them live? 
3. How do you reach these people?

4. Describe your organization and their use of social media.

5. What are some of the media tools that you use in order to get information out such as when new locations open?

6. How responsive are the consumers to the tools that you use?

\section{GOALS \& PERCEPTIONS}

1. What are some of the future goals for this organization?

2. What are some of the other possible areas for expansion or new location?

3. Describe the vision you have with farmers and vendors in the future.

4. What kind of challenges do you have when you try to get consumers to visit new or existing locations?

5. Describe the consumers' acceptance of the changes throughout the community with the local food initiatives.

6. How do they view the farmers' markets, Fresh Stops, and Healthy in a Hurry Corner Stores? (As a positive change or are they only there to get things for others who have asked? 
7. What is the biggest impact that you believe the farmers' markets, Fresh Stops, and Healthy in a Hurry Corner Stores have made within these communities?

\section{V.WRAP-UP}

Thank you. Those are all of the questions I have for you today.

[If observer in room, ask if the observer has any questions]

Do you have any questions for me?

If you have questions after you leave, you can reach me via the number I have given you. 


\section{APPENDIX D \\ INTERVEW GUIDE FOR FARMERS \\ INTERVIEW DISCUSSION GUIDE FOR FARMERS}

FEBRUARY 2012

\section{GREETING/WARM-UP_(3 MINUTES)}

- Thank participant for agreeing to be part of the study

- Introduce yourself and the purpose of the study - to learn more about their perspective on the farmers' markets, Fresh Stops and Healthy in a Hurry programs and how they view their relationships with African American consumers

- As we talk, I want to know about some of your experiences with the African American consumers, there are no right or wrong answers, just your thoughts and opinions

- Reminder of observation - I will record our conversation just for us, so that we can later remember some of the important things that you said. When I report the findings I will not identify you or your consumers in any way, I'll simply talk about things that people said overall 


\section{INTRODUCTION}

1. Why don't you begin by telling me a little about yourself. What do you do?

2. So tell me, how did you become a farmer/vendor? (Is farming something that your family has always done?)

3. Where is your farm located?

4. Tell me about the different types of crops that you grow?

5. Do you harvest on land that belongs to other farmers?

6. So lately we hear a lot about everything being organic. Tell me about some of the organic products that you grow.

7. In general, how long would you say that you have been a part of the farmers' markets?

8. Where are some of the locations that you sell your products at in West Louisville and East Downtown?

9. How many markets do you sell at overall?

10. Tell me about selling your crops at the farmers' markets and Fresh Stops?

a) Why do you sell at the farmers' markets instead of the Fresh Stops?

b) Why do you sell at the Fresh Stop instead of the farmers' markets? 
11. What about the difference in location? Tell me about some of the things that you notice.

12. How do you adapt to the different populations and cultures?

13. What types of interactions do you experience at the farmers' markets and Fresh Stops?

14. Some people enjoy cooking and trying new dishes. Describe any menus that you may offer to the consumers.

15. When you provide suggestions, are all populations accepting?

16. How often do the consumers ask or want to know about your products?

17. Tell me about your consumption of fruits and vegetables?

18. In general tell me some of the reason why there is a need to push to provide these markets?

19. How often do you hear consumers talking about eating healthy?

20. So tell me, after doing this for the length of time that you have been, what are the changes that you see within the community?

21. What are some of the health related concerns and questions consumers have?

22. How often are you asked about eating certain products while having conditions such as diabetes?

23. Describe what you think is the most important diet related health concern?

24. What are your thoughts on obesity? 
25. What are your thoughts on heart disease and diabetes?

\section{F\&V ACCESS AND SHOPPING BEHAVIOR}

1. Describe your shoppers.

2. Where do most of them live?

3. What are the shoppers buying?

4. Tell me about shopping lists. How often do you see shoppers with a list? I think a list would indicate that he or she REALLY wants specific items.

5. Tell me about the most popular products.

6. What are some of the specific items shoppers might ask for?

7. Explain the purchasing habits among shoppers who buy certain foods.

8. Tell me about the odd vegetable that people just do not seem to buy.

9. How do you get the shopper to buy the odd vegetable or one that they have a negative concept about?

10. When you have a really big harvest of a certain crop that does not seem to sell, what are some of your strategies for selling?

11. Where are the best prices?

12. How often do people complain or try to negotiate?

13. Tell me about some of the conversations. How often do shoppers talk about the difference the markets and fresh stops have made?

14. What are some of the things they say about shopping with your vs. shopping at a nearby Kroger? 
15. What is their overall attitude now that they have access to things that may have been limited before?

16. Tell me, how are these Fresh Stops different today? (More shoppers)

\section{RELATIONSHIP}

You see the consumers and possibly develop some type of bond with them:

1. How does this bond or relationship usually start?

2. Tell me about the repeat consumers.

3. What types of questions do they ask you?

4. What kind of challenges do you have when trying to offer your products to this population?

5. What key pieces of information do you make sure to tell them?

6. How do you feel in general about the relationships that you have with your consumers?

7. Tell me about your relationships within the community.

8. What benefits come along with the relationship? (You learn what they like? They receive educational info?)

\section{PERCEPTIONS OF F\&Vs}

When the consumers talk about eating what kinds of foods do you hear them talk about most often?

1. Have you heard consumers talk about how their diets? 
2. When a consumer tells you what they intend to make with your products, what details do they provide about preparation methods?

3. How often does the consumers know which kinds of foods give the best nutrients? Can you give me a few examples of what you would tell the consumer? (food $\rightarrow$ nutrient)

a. How many consumers indicate if a health care professional told them that they should add more fruit and vegetables to their meals? How do they seem to feel about this when a healthcare professional makes recommendations?

b.What are some of the needed dietary changes they discuss?

\section{FARMERS' MARKETS AND FRESH STOPS}

1. Are the consumers aware of the different locations of the markets and stops?

2. How do they seem to find out?

3. Describe the consumers' acceptance of the changes throughout the community with the local food initiatives?

4. How do they view the farmers' markets, Fresh Stops, and Healthy in a Hurry Corner Stores? (As a positive change or are they only there to get things for others who have asked?

5. What is the biggest impact that you believe the farmers' markets, Fresh Stops, and Healthy in a Hurry Corner Stores have made within 
these communities?

\section{WRAP-UP}

- Thank you. Those are all of the questions I have for you today.

- [If observer in room, ask if the observer has any questions]

- Do you have any questions for me?

- If you have questions after you leave, you can reach me via the number I have given you. 


\section{CURRICULUM VITAE}

Natasacha Ryan Jones

Department of Communication

310 Strickler Hall, University of Louisville

Louisville, Kentucky 40292

Phone: (502) 852-6976

Email: Natasacha.Jones@Louisville.edu

\section{RESEARCH INTERESTS}

-African American Communication

-Health Communication

-Interpersonal Communication

\section{EDUCATION \& TRAINING}

M.A. University of Louisville, Louisville, Kentucky Projected May 2012

-Thesis: Building Bonds \& Promoting Healthy Choices: Exam Farmers' \& Vendors' Relationships With African American Consumers

-Thesis Director \& Committee Members: Drs. Jennifer Gregg, Lindsay Della \& Kristi King 
B.A. University of Kentucky, Lexington, Kentucky May 2010

\section{PROFESSIONAL PROFILE}

University of Louisville

Louisville, Kentucky

Graduate Teaching Assistant, Department of Communication

August 2011-Present

University of Kentucky Clinic

Lexington, Kentucky

September 2006-May 2009

Intern \& Advocate, March of Dimes, Louisville (2007)

\section{COURSES TAUGHT}

University of Louisville, 2011-2012

COMM 111-22: Introduction to Public Speaking, Fall 2011, enrollment 24 students

COMM 111-24: Introduction to Public Speaking, Fall 2011, enrollment 24 students

COMM 111-13: Introduction to Public Speaking, Spring 2012, enrollment 24 students

COMM 111-25: Introduction to Public Speaking, Spring 2012, enrollment 24 students

\section{PROFESSIONAL AFFILIATIONS}

-Kentucky Communication Association 
-Southern States Communication Association

\section{RESEARCH \& CONFERENCE PRESENTATIONS}

A. Regional and State Conference Paper Presentations

1. "Waiting to Inhale: An Analysis of Publication Patterns on Smoking and Tobacco," Presented (with other researchers on the project) at the Kentucky Communication Association Conference, Cadiz, Kentucky, September, 2011.

2. "McDonald's Sunrise: Graduate Research Team Experiences." Presented (with other researchers on the project) at the Kentucky Communication Association Conference, Cadiz, Kentucky, September, 2011.

3. "Understanding Patient-Physician Gender \& Race/Ethnicity Concordance/Discordance." Presented at the Southern States Communication Association Conference, Memphis, Tennessee, April, 2010.

\section{SYMPOSIUMS}

2012 University of Louisville Graduate Student Symposium, Louisville, Kentucky

\section{UNIVERSITY SERVICE}

A. University of Louisville Graduate Student Ambassador 2011-Present

B. Test Proctor January 2012-May 2012 


\section{FELLOWSHIPS \& SCHOLASTIC AWARDS}

A. Strategic Plan Tuition Award 2011-2012

University of Louisville, Award for Fall 2011 through Spring 2012

\section{COMMUNITY SERVICE}

A. Volunteer, Center For Accessible Living, Louisville (2010)

\section{REFERENCES}

Dr. Jennifer L. Gregg

Director of Graduate Studies

University of Louisville

Department of Communication

(502) $852-8177$

Jennifer.Gregg@louisville.edu

Dr. Lindsay Della

Assistant Professor

University of Louisville

Department of Communication

(502) 852-6976

Ljdel101@Iouisville.edu 